Article

\title{
A Cultural Route Perspective on Rural Revitalization of Traditional Villages: A Case Study from Chishui, China
}

Zijie Zhou and Xin Zheng *

School of Architecture, Southeast University, Nanjing 210096, China; zijie@seu.edu.cn

* Correspondence: przheng@163.com

Citation: Zhou, Z.; Zheng, X. A Cultural Route Perspective on Rural Revitalization of Traditional Villages: A Case Study from Chishui, China. Sustainability 2022, 14, 2468. https:// doi.org/10.3390/su14042468

Academic Editor: Chiara Garau

Received: 6 January 2022

Accepted: 18 February 2022

Published: 21 February 2022

Publisher's Note: MDPI stays neutral with regard to jurisdictional claims in published maps and institutional affiliations.

Copyright: (C) 2022 by the authors. Licensee MDPI, Basel, Switzerland. This article is an open access article distributed under the terms and conditions of the Creative Commons Attribution (CC BY) license (https:// creativecommons.org/licenses/by/ $4.0 /)$.

\begin{abstract}
Traditional villages along rivers have contributed significantly to local-regional development by transporting production and spreading culture through certain routes. To date, the cultural continuity of traditional villages has been underestimated in sustainable development with regard to practical dilemmas between conservation and development. This study explores an integrated approach to traditional villages in river basins that considers historic relics, locality, and spatial form. The cultural routes concept is introduced from the field of cultural heritage to link geographically scattered villages that shared the same cultural values and purposes in the past and to stimulate their potential as dynamic routes for further rural revitalization. In this context, the following subtopics are defined for a specific analysis of the lower Chishui River in Guizhou: an evolving framework of cultural routes and the spatial-temporal route of "Sichuan salt into Guizhou", including its contemporary transformation. The findings of cultural and spatial coherence in historical texts, maps, morphological structures, and rural landscapes support a multi-cultural route model for sustainable development. The study extends the prevailing knowledge on cultural sustainability in rural revitalization and it provides novel insights into spatial development in basin environments.
\end{abstract}

Keywords: traditional villages; cultural routes; rural revitalization; historic evolution; sustainable development

\section{Introduction}

Human-river relations have brought mobility to the relatively fixed human-land relations in past agricultural societies, conferring diversity and local identity in terms of culture and human habitat. Despite the essential gifts rural settlements offer us, many are at growing risk due to various factors: from the urbanization and depopulation of rural communities to river pollution, ecological destruction, and the loss of traditional culture. Researchers note the need to strengthen nature-culture linkages [1-3], especially in the context of China's rapid modernization process. Previously in rural China, modern practices resulted in a universal phenomenon of the same image in different regions regardless of local characteristics or traditional merits. This suggests that the urban methodology and design paradigm derived from modernism have not been directly applied to rural revitalizations in spite of certain human-land relationships [4]. Therefore, the purpose of this paper is to adopt a dynamic perspective on cultural routes for the conservation and the development of traditional settlements on the basis of the locality. Three types of contributions are addressed in this paper: interpreting long-established human-land and human-river relationships, acquiring traditional experience and local wisdom, and considering their transformation and expression in contemporary conditions.

The study in China began in the 1980s [5-7], but it was neglected for decades due to the onset of rapid urbanization in the 1990s. In 2012, a national mapping survey of rural settlements was launched to identify a national catalog of traditional villages. At the institutional level, the 19th Party Congress (2019) made a major decision to implement the strategy of rural revitalization; it is comprehensive and it includes cultural and ecological 
revitalization [8]. The law on the promotion of rural vitalization issued in April 2021 serves as a long-term institutional guarantee for rural areas [9].

Recent studies have suggested a variety of research methods from urban design and architecture. For instance, urban morphological theories and methods originating in the UK have been proven to be applicable to the study of historic districts in urban areas [10-12]. In addition, architectural discussions on Rossi's typological theory [13-15] and Hillier's space syntax have continued to influence many urban and rural researchers [16,17]. Taking into consideration the natural background, the application of urban approaches appears to be relatively limited in rural issues. The most fundamental distinction between urban and rural areas is whether the scale of settlements is strictly circumscribed by the geographical terrain: agglomerative or dispersed and mobile or fixed. In rural areas, the influence of nature on settlements far outweighs the human-made modifications of the natural environment. Therefore, it is necessary to recall the adaptability and sustainability of local cultural heritage with respect to the natural environment.

This paper introduces the concept of cultural routes to link geographically dispersed villages for a systematic study [18]. This concept was originally proposed in the field of cultural heritage and it represents a specific historic phenomenon of human mobility and exchange that developed along the route of communication for a specific purpose [19]. To identify cultural routes, three mandatory conditions must be fulfilled according to the charter promulgated by the International Council on Monuments and Sites (ICOMOS) in 2008 [20]: (a) it must arise from and reflect interactive movements of people as well as multidimensional, continuous, and reciprocal exchanges of goods, ideas, knowledge and values between peoples, countries, regions, or continents over significant periods of time; (b) it must have thereby promoted a cross-fertilization of the affected cultures in space and time, as reflected both in their tangible and intangible heritage; and (c) it must have integrated the historic relations and cultural properties associated with its existence into a dynamic system. Various empirical studies have been conducted on group heritage conservation. Most have focused on the cultural heritage of the corridor of human civilization across time and space, building multi-actor approaches in different regions [21-24]. Subsequently, this concept attracted the attention of urban researchers due to its intrinsic spatial properties. Current studies have developed a multi-dimensional and multi-scale vision of cultural routes in urban conservation and renewal [25-27]. Correspondingly, some linear rural settlements that contain cultural heritage are applicable to the research framework of cultural routes [28].

The cultural route is a feasible strategy for rural revitalization of villages with historical value. According to the Strategic Plan for Rural Revitalization (2018-2022), the proposed revitalization will make a classified promotion according to the: history and culture, developmental status, geological location conditions, resource endowments, and industrial foundation of rural areas. As one of the four advancement strategies, feature conservation mainly targets villages with rich natural historical and cultural characteristics such as famous historical and cultural villages, traditional villages, and villages with ethnic minority characteristics, which are important carriers of manifesting and inheriting excellent traditional Chinese culture. The strategic plan emphasizes the integrity, authenticity, and continuity of traditional villages. These attributes are notably reflected in the cultural itinerary that connected the villages into a dynamic whole. Thus, cultural routes may make reasonable use of the village's special resources, develop rural tourism and special industries, and form a positive and mutually reinforcing mechanism for the protection of special resources and the development of villages.

Previous research has been conducted to obtain a deeper understanding of Chishui cultural landscapes while focusing on (1) the cultural and economic influence of "Sichuan salt into Guizhou" [29,30]; (2) the preservation of historical and cultural sites [31]; and (3) Chishui's transportation role [32]. Research from urban and architectural professions, although still scarce in the Chishui River area, is emerging in human settlements and ecological sustainability. Recently, researchers have examined the effects of survival rationality on 
spatial evolution and rural landscape heritage as a "growing whole" spatial pattern [33,34]. A considerable amount of literature has been published on the Red Culture for the famous event crossing the Chishui River four times [35].

However, far too little attention has been given to the relationship between human settlements and the environment through a development perspective. To date, many topographic studies of rural settlements have assessed ecological and geographical indicators; yet, few studies have explained how these factors contribute to the process of the spatial formation of villages. On the other hand, most studies of cultural routes have primarily focused on the heritage value of the route itself and failed to attach these values to practical revitalization.

The paper seeks to analyze traditional villages on the cultural route by explaining their cultural identities and spatial potentials to prepare for the challenging task of establishing connections between the past and the future. This study helps to answer the following questions:

1. How can cultural heritage be identified in rural settlements that have the potential to form cultural routes?

2. How was the cultural route formed and changed? How have these productive activities along the route shaped the spatial structure of rural settlements and influenced the relationship between humans and nature?

3. How can traditional villages be revitalized through the lens of culture and landscape?

The remaining sections of this paper are organized as follows. In the next section, the research materials and methods are presented, including the study area, data, and methods. The third section proposes an evolving framework of cultural routes, describes the primary empirical results of historical analysis and field survey in Chishui, and puts forward a strategic model of multi-cultural routes. The paper concludes with a discussion and conclusions which consider the principal findings, limitations, and avenues for future research.

\section{Materials and Methods}

\subsection{Study Area}

The study area is located in Chishui, the northern gateway of Guizhou Province in southwest China (see Figure 1). At the border of the Yunnan-Guizhou Plateau and the Chengdu Plain, Chishui River (literally 'Red Water River') played a crucial role in regional economic exchange and military status. This study selected seven traditional settlements in the middle and lower reaches of the Chishui River under the administration of the Chishui county-level city (between $105^{\circ} 36^{\prime} \sim 106^{\circ} 14^{\prime} \mathrm{E}$ and $28^{\circ} 15^{\prime} \sim 28^{\circ} 45^{\prime} \mathrm{N}$ ). These villages have effectively preserved their traditional location, structure, pattern, style, and idyllic landscape since the 17th century (see Figure 2). Among them, Datong and Bing'an have been assessed and included in the protection system for famous historical and cultural cities, towns, and villages in China. Moreover, Datong (2020), Bizhao (2016), and Bing'an (2012) were successively enrolled in the traditional village catalog. Therefore, these traditional villages of great historical value and cultural heritage can be categorized as the characteristic conservation type of rural revitalization.

\subsection{Data}

The study materials consist mainly of historical sources and geographical data. First, historical information is collected through governmental records, local gazetteers, and statistical data. By administrative region, the official documents are the Guizhou General Records 贵州通志 (1741), Renhuai Zhili Department Records仁怀直隶厅志 (1840), and Chishui County gazetteers赤水县志 (1990). It is worth noting that the administrative relationship in the region has changed several times throughout history, causing ambiguous references with regard to place names. For example, Renhuai port, as one of the four ports of the Chishui River, did not refer to today's Renhuai City near Maotai in the middle reach but 
to the old name of Chuishui City in the lower reach. The retrieved data in this paper are converted according to the current usage.

Specifically, within the scope of "Sichuan salt into Guizhou," more historical materials related to Chishui River settlements have been collected. Thereinto, Sichuan Yanfa Zhi 四川 盐法志 (Gazetteers of Salt Industry of Sichuan) was an important official book reflecting the situation of salt affairs during the Qing Dynasty. These forty volumes were edited by Ding Baozhen, the governor of Sichuan Province who hosted the Salt Reform during the Guangxu period (1876-1886). Historical maps and woodcut paintings from Yanfa Zhi are valuable materials for understanding the social and spatial environment. In particular, Vol. 10 carefully documented the salt industry, and transportation and trade along the Chishui River in Guizhou. Another salt law from a national perspective, Qing Yanfa Zhi 清盐法志 (Gazetteers of the Salt Industry in Qing Dynasty) was finished in 1920 by the National Salt Bureau and provided information on the Chishui River in volumes on Sichuan. This cyclical economic-social activity of "Sichuan salt into Guizhou," which was nationally regulated and locally practiced, manifests as a cultural phenomenon that provides rich historical information.

Second, this paper presents geographic data analysis using a 12.5-m DEM at highresolutions (RT1) acquired with ALOS-PALSAR (open source). Spatial data were also compared with the results of field research and high-resolution remote sensing images from OpenStreetMap and Google Earth. These original RTC GeoTIFF products were visualized and analyzed in ArcGIS 10.7. Dataset: ASF DAAC 2015, ALOS PALSAR_Radiometric_Terrain _Corrected_high_res; includes material @ JAXA/METI 2009. Accessed through ASF DAAC, DOI: https:/ / doi.org/10.5067/Z97HFCNKR6VA (accessed on 22 April 2021).

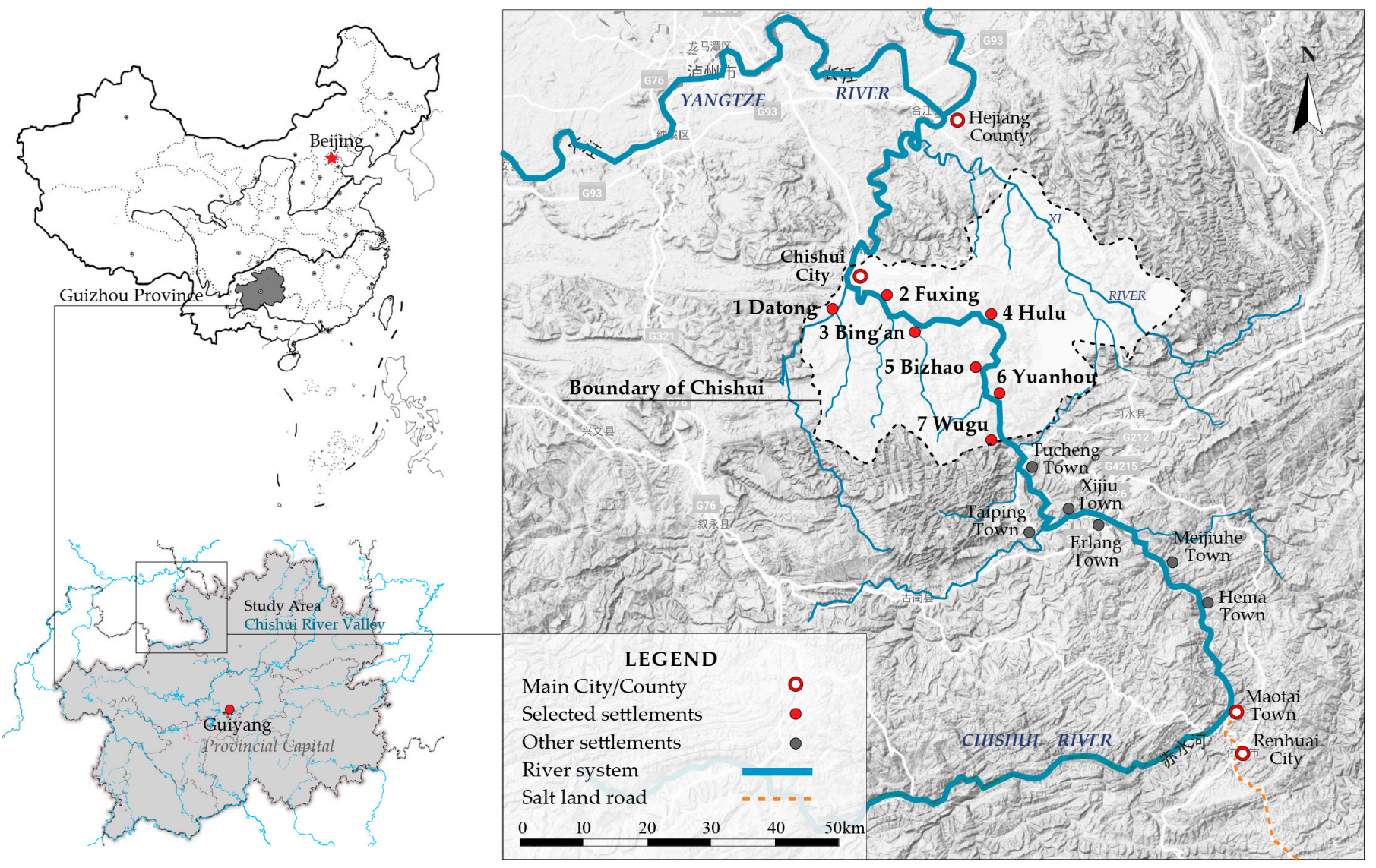

Figure 1. The location of the traditional settlements in Chishui, China. Source: authors' own elaboration. 

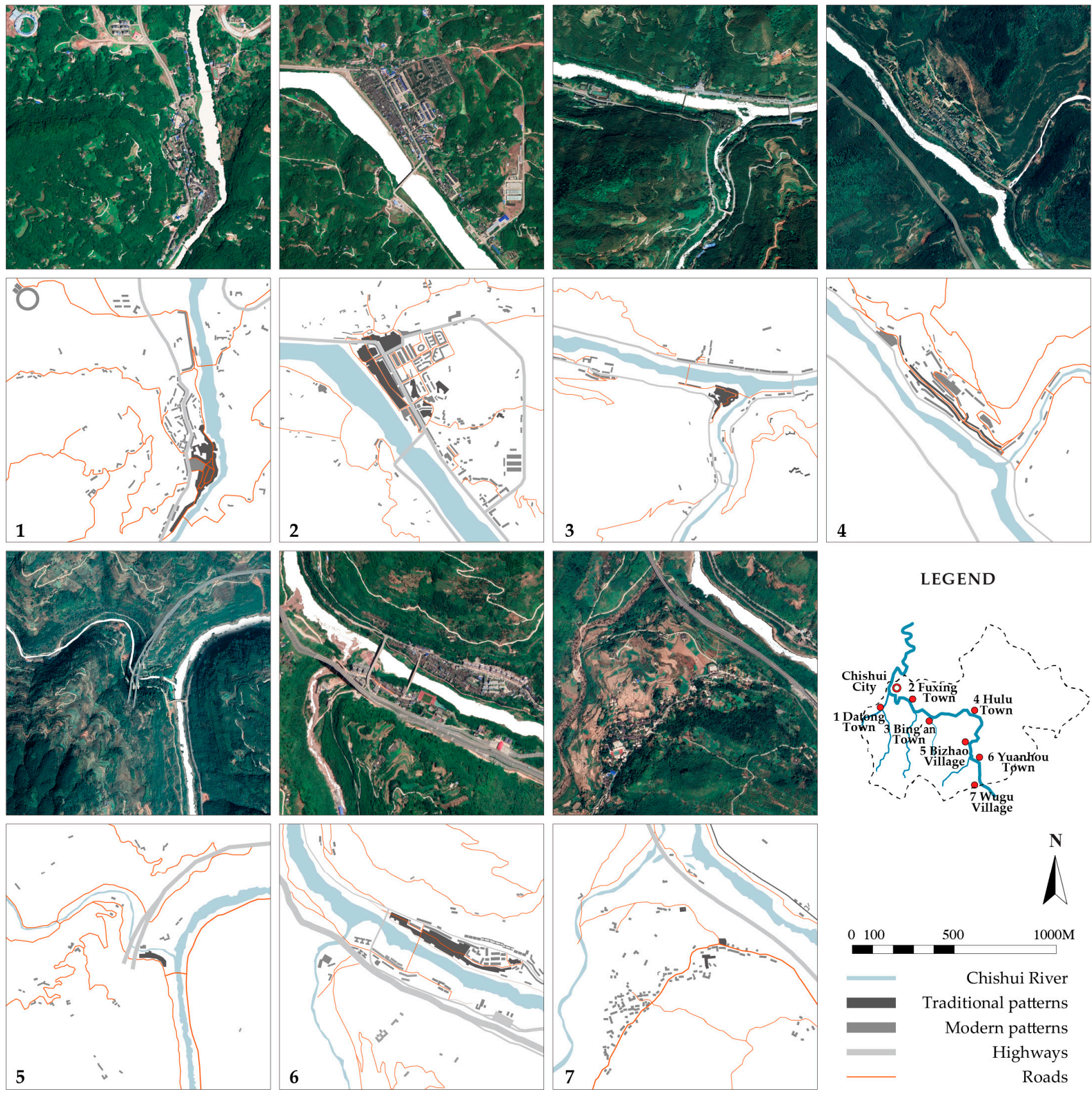

Figure 2. Spatial structure of the selected traditional settlements. Source: Google Earth.

\subsection{Methods}

Field surveys are the fundamental way to obtain intuitive spatial data. Spatial experience is indispensable in the study of morphological issues, especially human settlements in mountainous terrain. Moreover, world view and the natural environment are closely related: one's world view, unless it is derived from a foreign culture, is necessarily constructed from the elements of one's social and physical setting [36]. Thus, the best way to perceive the relationship between humans and the environment is to place oneself in a certain location [37]. Conducted in 2019, the field survey of this study paid close attention to the spatial organization within villages and the relationship between groups and the environment. Interviews were conducted with local people. Questions were asked about past and present lifestyles, production methods, habitat, household composition, village 
history, and the age of the buildings. Through fieldwork, the commonness of the cultural landscape in series was revealed, suggesting the research idea of the cultural route.

Historical analysis was mainly conducted through literature research, supplemented by oral histories. Mapping methods are particularly applied in space and time analysis through the spatial translation of historical maps, and they are used to stratify and integrate historical information in geography [38]. The morphological analytical methods of architectural and urban studies are universal in settlement research to examine the internal drivers and motives of space from a historico-geographical perspective [39,40]. In addition, topographic analysis was performed with the application of the digital tool GIS to scientifically validate empirical judgments about the natural environment.

\section{Results}

\subsection{An Evolving Framework of Cultural Routes}

Through traditional villages, an evolving framework of rural revitalization and cultural routes can be established, in terms of the inherent properties of both (see Figure 3). First, among the four major types of rural revitalization promotion, the feature conservation type basically refers to traditional villages with historical value and cultural heritage. Second, traditional villages constitute the elements of cultural routes from points to line. These villages as elements must share the associated characteristics of cultural routes in three ways. Finally, cultural routes have striking potential to promote rural revitalization from line to region, through an evolving strategy.

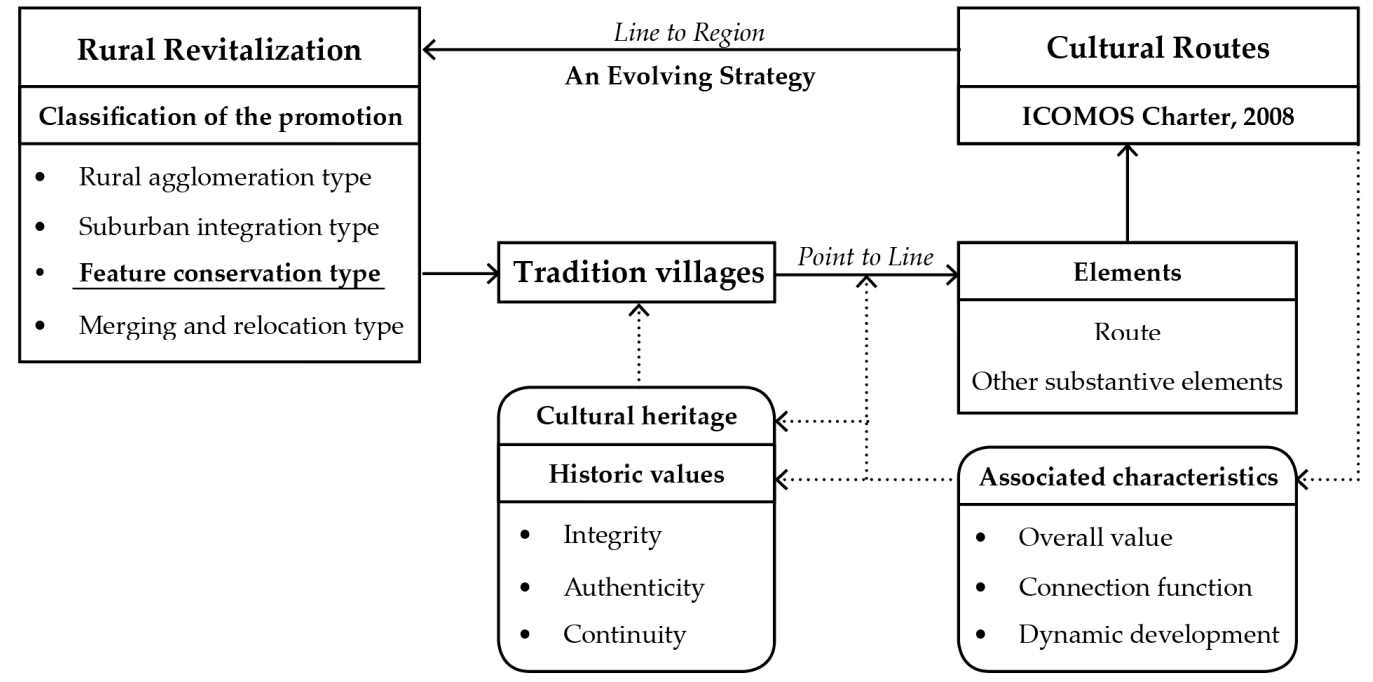

Figure 3. An evolving framework of cultural routes and rural revitalization. Source: Strategic Plan for Rural Revitalization (2018-2022) by the State Council of the PR China; Charter on Cultural Routes (2008) by the ICOMOS.

\subsubsection{Characteristics Associated with Traditional Villages}

Consensus has been reached regarding the importance of cultural routes to heritage protection. Beyond a category of cultural heritage ontology, it has become a planning perspective that plays an active role in the construction of multiple objectives, including environmental governance, cultural industrial development, and convenient local living [41]. With cultural integration as the core, it is possible to realize a multi-dimensional revival of traditional settlements for the following associated characteristics.

- The overall value of cultural routes. The cultural route connecting a series of spatially dispersed traditional settlements demonstrates value as a whole, transcending each part that shares a substantial number of characteristics and a value system.

- The connecting function of the cultural corridor. The linear transportation entities are infiltrated and linked with the material and immaterial derivatives around the 
cultural routes. This structure can promote the renewal of decaying communities and infrastructure along the route, forming a continuous public space with cultural themes.

- The perspective of dynamic development. In the past, different communities conducted cultural exchanges and integration through the route. Currently, it is an extension of spatial and temporal dimensions as well as the dialog between the past and the future. Attention should be given to the role of the route in promoting the exchange of different groups recently, implementing it in spatial construction, integrating the cultural route into the process of rural revitalization, and promoting the harmonious coexistence of historical heritage and contemporary society.

\subsubsection{Elements of the Cultural Route in Chishui}

The first step is to identify and investigate the elements on which further research is based. According to the charter, the classification is adapted in the Chishui River basin, its constituent elements are clarified through field research, literature study, and other methods; and, the elements in the geographical information platform are itemized and described (see Table 1).

Table 1. Element classification.

\begin{tabular}{|c|c|c|c|c|}
\hline & & & Past & Present \\
\hline \multirow{4}{*}{ Route } & \multirow{3}{*}{$\begin{array}{l}\text { Physical } \\
\text { Elements }\end{array}$} & Waterway & $\begin{array}{lr} & \text { Mainstream, Tributaries, Port } \\
\text { Tools } & \text { Different sizes of ships }\end{array}$ & \multirow{3}{*}{$\begin{array}{l}\text { All-year navigation } \\
\text { Viaduct, Highway, } \\
\text { Tunnels }\end{array}$} \\
\hline & & Land & Valley Road, Streets in towns, Bridges & \\
\hline & & Road & Pickers, Horses & \\
\hline & $\begin{array}{l}\text { Human } \\
\text { Activities }\end{array}$ & Goals & 'Sichuan salt into Guizhou' & $\begin{array}{l}\text { Closed fishing; } \\
\text { Ecological restoration }\end{array}$ \\
\hline \multirow{9}{*}{$\begin{array}{l}\text { Other } \\
\text { Substantive } \\
\text { Elements }\end{array}$} & \multirow{7}{*}{$\begin{array}{l}\text { Tangible } \\
\text { Heritage }\end{array}$} & \multirow{5}{*}{$\begin{array}{l}\text { Human } \\
\text { Settlements }\end{array}$} & $\begin{array}{l}\text { Central Hall, Fire Pond, Wood } \\
\text { Structure } \\
\text { Rooftop Food Storage }\end{array}$ & \multirow{5}{*}{$\begin{array}{l}\text { Tourist service facilities, } \\
\text { Schools, Dwellings, } \\
\text { Government institutions }\end{array}$} \\
\hline & & & $\begin{array}{l}\text { Temple, Guild Hall, Pavilion, } \\
\text { Retails } \\
\text { Celebrities' former residence, } \\
\text { Accommodation, Dwellings }\end{array}$ & \\
\hline & & & Dock, Bridge, Boundary stone & \\
\hline & & & Square, Street, Lane, Yard & \\
\hline & & & Market, Bazaar, Festival site & \\
\hline & & \multirow{2}{*}{ Nature } & Cultural landscapes & \multirow{4}{*}{ Tourism } \\
\hline & & & Mountain, River, Forest, Farmland, Benchland & \\
\hline & \multirow{2}{*}{$\begin{array}{l}\text { Intangible } \\
\text { Heritage }\end{array}$} & local & $\begin{array}{c}\text { Tourism } \\
\text { Nature worship, Living habits, Dragon king worship }\end{array}$ & \\
\hline & & Immigration & $\begin{array}{l}\text { Shipping technology, Trade culture } \\
\text { Central plain culture and custom } \\
\text { education and the imperial examinations }\end{array}$ & \\
\hline
\end{tabular}

* Authors' own elaboration.

Through the refinement of the elements, what stands out in the table is the cultural route ontology of "Sichuan salt into Guizhou" and other basic substantive elements, particularly the tangible heritage associated with the development of human settlements. The route ontology constructs the historical process of the route, transportation network, and historical events that influence the route. Other spatial elements mainly revolve around the ecological context, the settlement-water relationship, and the old-new relationship that is closely related to the evolution of traditional settlements [42]. These analytical procedures and their results are described in the next sections.

\subsubsection{Topographical Basis for Cultural Routes}

Rivers and mountains play an important role in cultural routes. The Guizhou plateau is divided into two major river basins by the Miaoling Mountains. In the north, five rivers 
including the Chishui River flow directly into the Yangtze River system, while in the south the rivers join the Pearl River system. As a major tributary of the upper Yangtze River, the Chishui River has been developed as a transportation route of "Sichuan salt into Guizhou" since the 18th century. Cutting through dense mountains and karst terrain, no large plains were formed in the Guizhou Plateau for mass aggregation. Therefore, the valley basins are most suitable for human settlement. Villages along the river are usually on a small scale and even commercially developed due to the limitation of specific topographical conditions.

Chishui is located in the transition zone from the Yunnan-Guizhou Plateau to the Sichuan Basin. The altitude decreases from southeast to northwest with large topographic relief. The highest elevation is up to $1730 \mathrm{~m}$ in Hulu and the lowest elevation is $215 \mathrm{~m}$ in Baiyun. The Chishui River and Xishui River flow southeast to northwest, forming a distinct landform feature of "two valleys, one ridge, and four slopes". The exposed stratum is Jurassic and Cretaceous red sand shale, strongly folded, denuded, and cut, forming a peculiar Danxia landscape. The region has a humid monsoon climate in the mid-subtropics, with abundant rainfall and frequent frost-free periods. It combines the characteristics of high temperature and humidity in southern Sichuan; abruptly warm and cold weather on the Guizhou Plateau; and significant vertical differences, which are suitable for the growth of subtropical plants. The forested area rapidly increased to 148,600 hectares in 2019 from 138,591 hectares in 2006 due to the return of the grain plots to forestry. Accordingly, forest coverage increased from $71.3 \%$ to $82.5 \%$.

The overall spatial distribution of human settlements in Chishui County demonstrates a "two clusters and two lines" structure, "one straight and one tortuous," based on the ArcGIS tool analysis (see Figure 4).

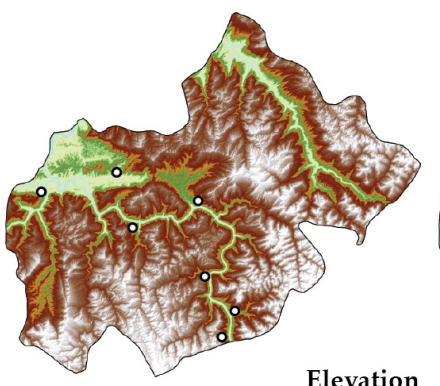

Elevation
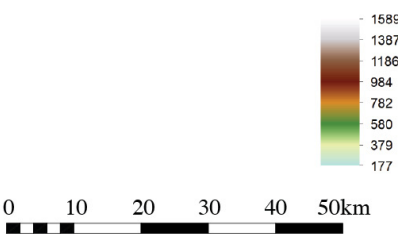

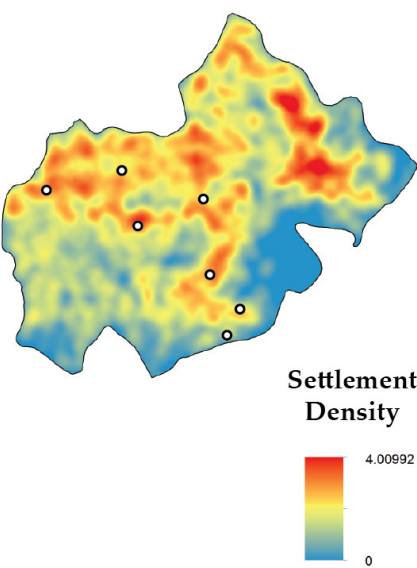

(b)

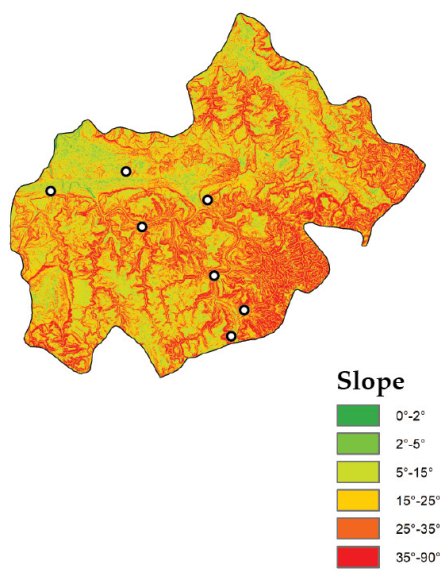

(c)

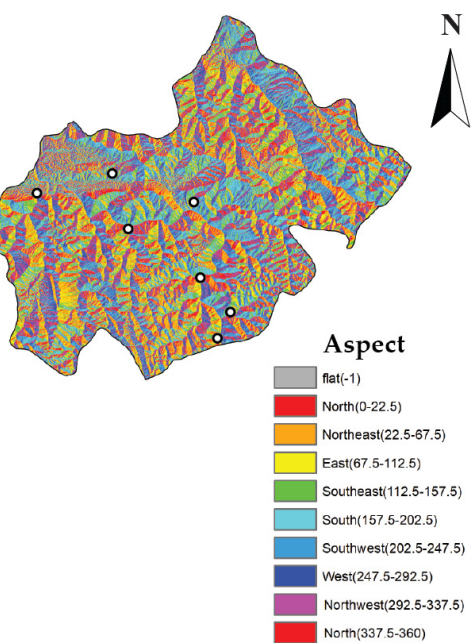

(d)

Figure 4. Topographical analysis of municipal Chishui. (a) elevation; (b) settlement density; (c) slope analysis; (d) aspect analysis. Dataset: ASF DAAC 2015, ALOS PALSAR_Radiometric_Terrain_Corrected_high_res; Includes Material @ JAXA/METI 2009. Accessed through ASF DAAC 22 April 2021. doi: https:/ / doi.org/10.5067/Z97HFCNKR6VA.

1. Two main clusters: In the northwest, the triangle, lowland downtown areas are the most widely populated, where the terrain undulates slowly along the ridge less than $500 \mathrm{~m}$; the fan area next to it is a hilly, low mountain basin, with a gentle topography of approximately $600 \mathrm{~m}$ on average. Both clusters share some similar geographic traits: the slope ranges from 5 to 15 degrees, and the slope aspect is delicately segmented.

2. Two valley lines: Settlements aggregate alongside the mountain canyon and river valleys, forming two linear distributions of the Chishui River and Xishui River. The lower reaches of the Xishui River are much broader than those of the Chishui River, resulting in a relatively wider buffering zone capable of more towns and villages. 
3. The selected traditional settlements are all located along the Chishui River, and their spatial distribution follows the river's zigzag trend, forming a meandering linear route. The topographic conditions of the mountains dictate that settlements can only expand linearly in a narrow space sandwiched between the foot of the mountains and the river's edge.

The topographic framework thus implies that its physical scope greatly overlaps with the cultural route. This demonstrates that the occurrence and spread of a civilization is inseparable from the constraints of terrain conditions on living space. The site selection of the traditional settlements in the Chishui River basin conforms to the dual requirements of topographical context and cultural transmission, with corresponding cultural content and vitality in different eras. It is through respect for the laws of nature that humans can achieve sustainable development under rational constraints [43].

\subsection{Salt Transportation: Dynamics of the Evolution of Traditional Villages}

3.2.1. Background

Nationwide salt trade warranted a vast continental market with no impediment to the movement of goods across provincial boundaries in the Ming-Qing Dynasty. Under a state monopoly of licenses to transport salt, a substantial quantity of wealth quickly accumulated due to this source of revenue in Qing China. Among the three main types of salt production, well salt possesses strategic importance in terms of geographic distribution. Produced primarily in Sichuan, most notably in Zigong, well salt has dominated the overall market in Southwest China [44].

Guizhou has not produced salt since ancient times, making it a vibrant economic market that relies entirely on imports from other regions. Chuanyan Xingxiao zhi Gaiyao 川盐 行销之概要 (Summary of Sichuan salt sales) offers exact textual evidence that "Sichuan salt into Guizhou" started in the Yuan Dynasty (1271-1368 AD). According to the document, the royal horses herded in Yixi, Buxue and other regions in Guizhou were fed salt every month and were healthy and thriving. Chaos in Bo (播, place name) impeded Yunnan salt from entering Guizhou in time; consequently, these royal horses became sick and died. Therefore, the central state ordered Sichuan Province to transport salt into Guizhou. This indicates that before the Ming Dynasty (1368-1644 AD), Sichuan was not the only salt supply chain in Guizhou; other adjacent areas, such as Yunnan and Guangdong provinces, also participated in market competition. However, as stated in Yanjia Shuo 盐价说 (price of salt), "Guizhou salt mostly depends on Shu (Sichuan alias). If Shu is deficient, Guizhou people's food tastes bland." Since the Ming Dynasty, Sichuan Province has been the largest salt supplier of Guizhou Province.

Administrative changes in Chishui were so frequent that some historical evidence for "Sichuan salt into Guizhou" must be established by tracing clues from Sichuan. Specifically, there were few official documents or records about the Chishui River until 1413, when Guizhou officially became a Ming province. In 1381, Renhuai County (now Chishui City) was established under the Zunyi government of Sichuan Province. In 1728, it followed the Zunyi government in moving to Guizhou Province and renamed the Zunyi department in 1748. During the 41st year of Qianlong (1776), the Zunyi department was integrated into the Renhuai Zhili department, which was directly governed under the Guizhou Grain Storage Road. At the end of the Qing dynasty, the Chishui department was established and governed by the Zunyi government and it became a county in 1914 (see Figure 5).

\subsubsection{The Historic Route}

By the mid-Qing Dynasty, a complete transportation network for "Sichuan salt into Guizhou" was established that included both top-down political regulations and bottomup economic activities. The transportation system processes four steps of means and permissions, of which the study area accounts only for the third step (see Figures 6 and 7). 


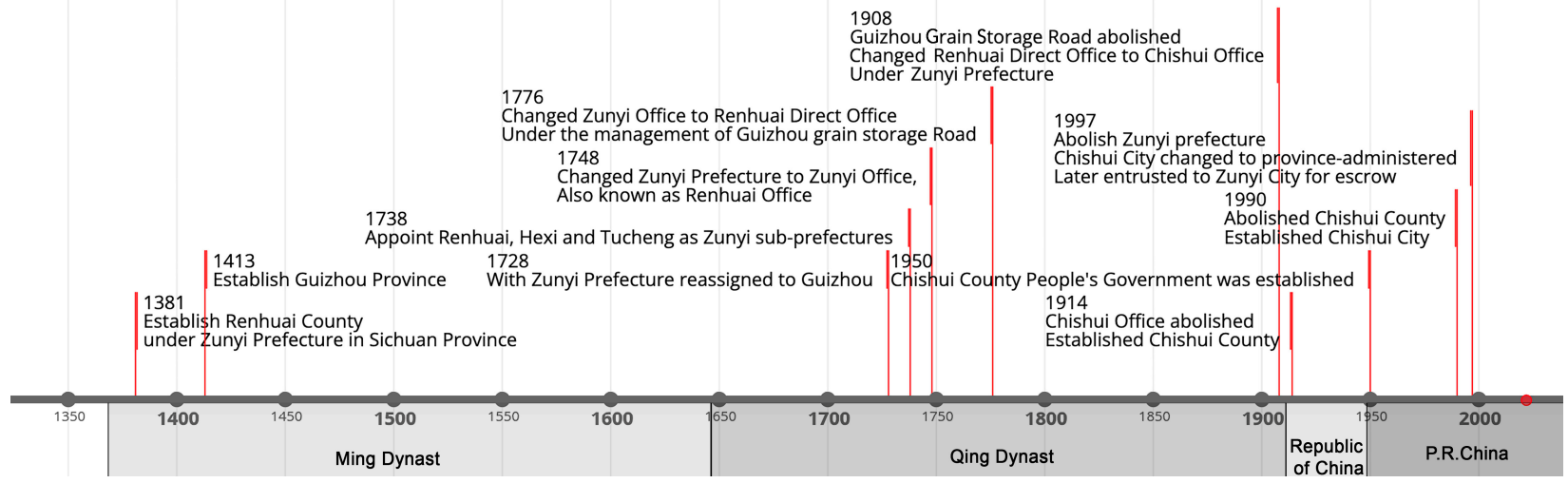

Figure 5. Timeline of Chishui's establishment. Source: authors' own elaboration.

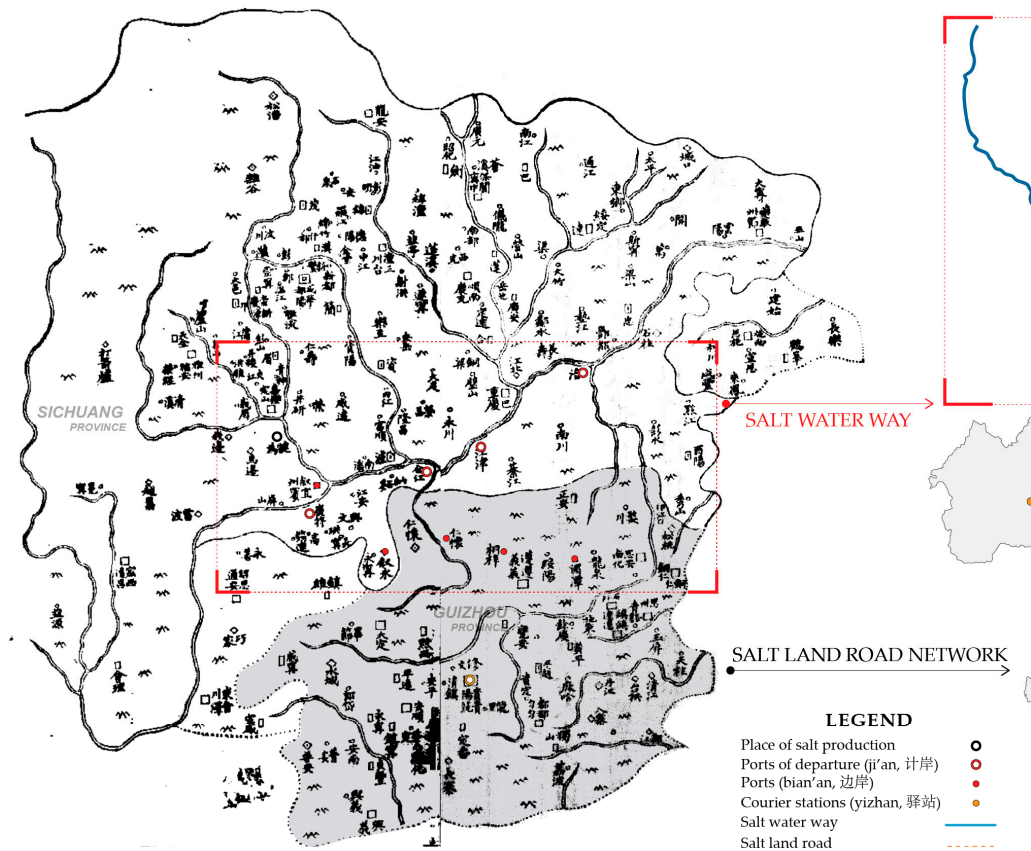

(a)

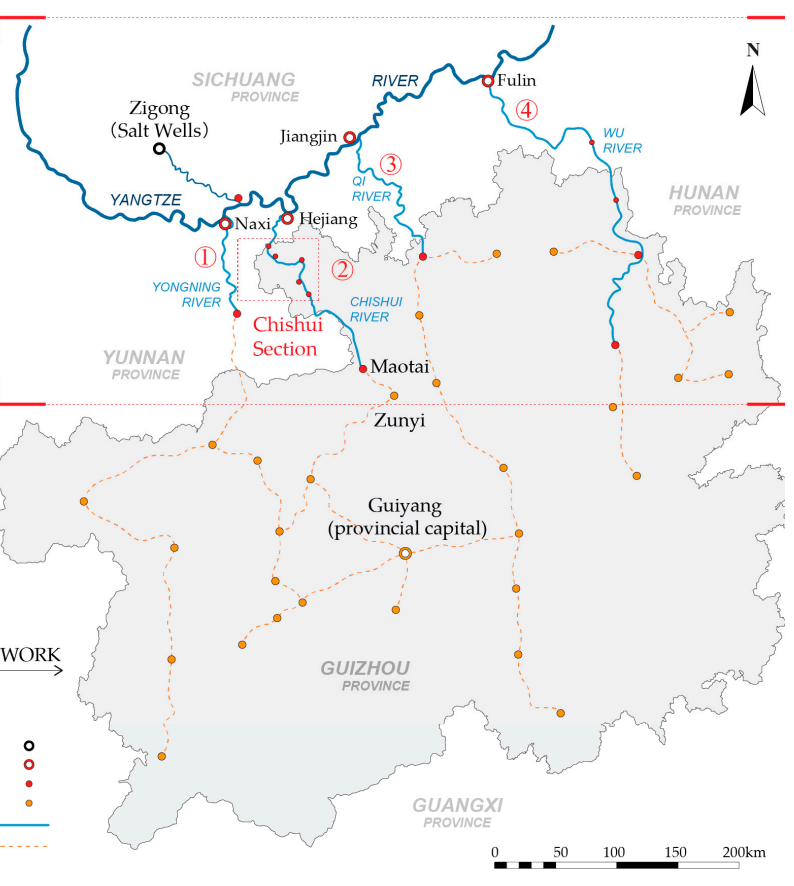

(b)

Figure 6. Spatial translation of historical maps of the salt transportation network. (a) The historical map of 'Sichuan salt into Guizhou'. Source: Sichuan Yanfa Zhi 四川盐法志 (Gazetteers of Salt Industry of Sichuan), vol. 6. (b) Mapping the salt waterway and land road network. Source: authors' own elaboration.

The Chishui section assumes an essential part of "Sichuan salt into Guizhou" from Hejiang to Maotai via water, destined mainly for Zunyi and Guiyang. The salt carriers had to go upstream and the channel turned from wide to narrow in this section. On dangerous shoals, dozens of packers were required to climb up rocks or sandbanks with ropes wrapped around their waists to tow the ship. Some particularly deep rushes required hundreds of people to work together. The riverbed from the Erlang Shoal to the Masang Plain was extremely narrow, turbulent, and dangerous. Precipices and cliffs on both sides often collapsed, blocking the river. This section failed to be repaired due to the underdeveloped technology of the Qing Dynasty, and there was not even a land path for horse transportation. According to poems, land transportation relied mainly on human labor. Strong packers were capable of carrying one hundred kilograms of salt, and even women carried half (see Figure 8). 


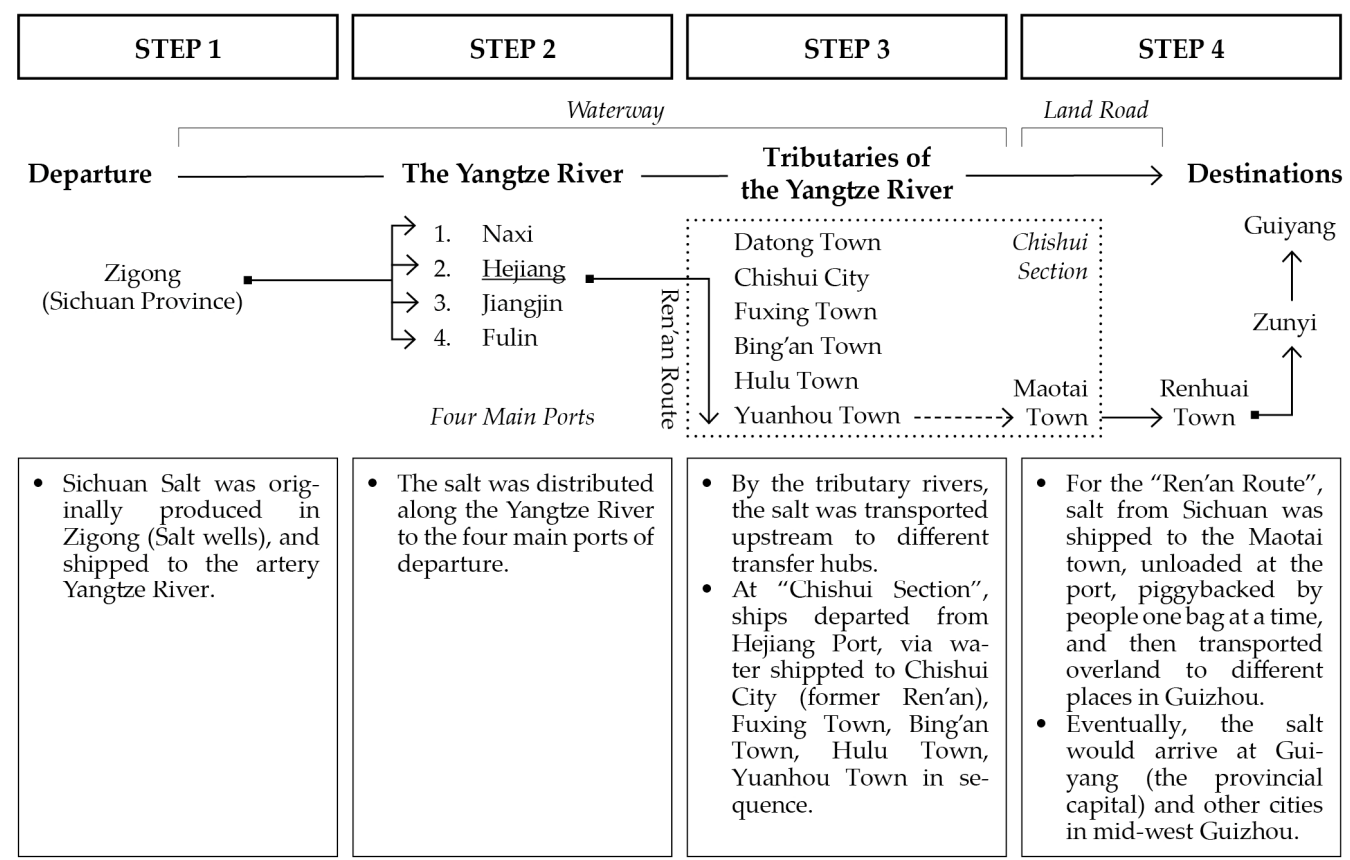

Figure 7. Salt Transport Flow Diagram. Source: authors' own elaboration.

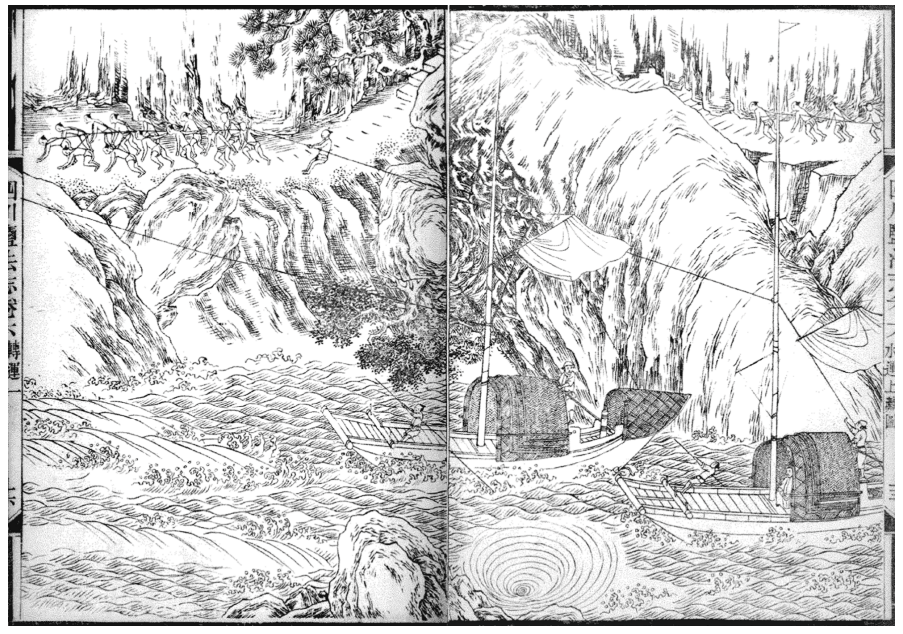

(a)

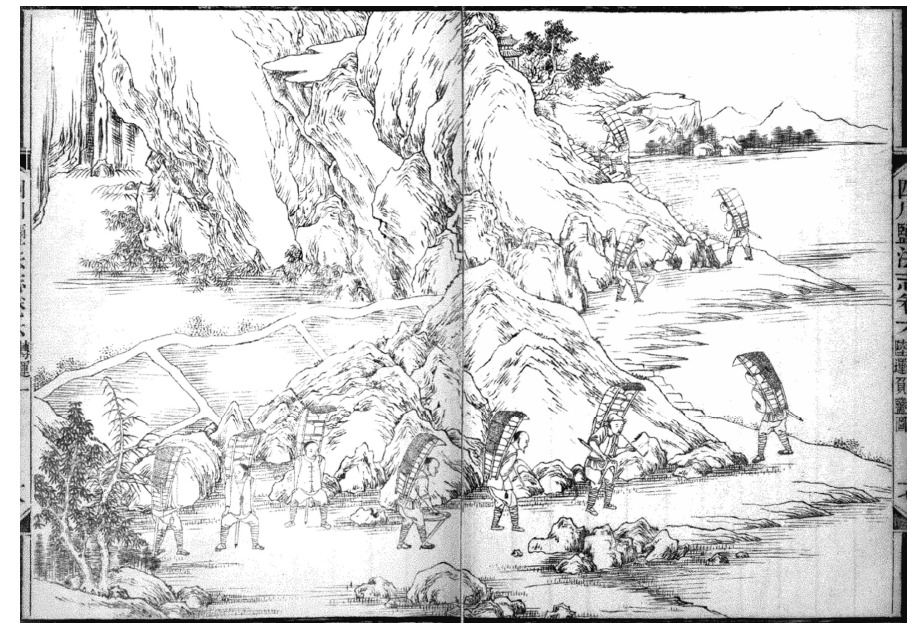

(b)

Figure 8. Illustrations depict the transportation scenes in the Chishui Section of "Sichuan salt into Guizhou". (a) Water transportation to the shoal水运上滩图. Dozens of packers climbed up rocks with ropes wrapped around their waists to tow the ship on dangerous shoals. (b) Land transportation by packers陆运负盐图. Packers carried out the transport of salt where the waterways were not dredged. Source: Sichuan Yanfa Zhi 四川盐法志 (Gazetteers of Salt Industry of Sichuan), vol. 6.

Hence, transportation activities gave rise to new occupations, accommodation requirements, and business trips to the local market. Immigrants from the Central Plain brought advanced technology, religion, culture, and education. This cyclical activity with economic and social characteristics profoundly influenced cultural development along the river, making Chishui an early developed region in Guizhou.

For the central state, the harsh and hostile terrain of the Yunnan-Guizhou Plateau represented natural barriers to outsiders. Therefore, a huge effort was needed to penetrate the area both institutionally and spatially. To maintain the route, several river channel dredging and salt policy reforms were carried out locally (see Table 2). These initiatives 
greatly improved the navigability of the Chishui section of the waterway and promoted economic development along the route.

Table 2. The significant events of Chishui River dredging before P.R. China (1949).

\begin{tabular}{|c|c|c|c|}
\hline Year & Dynasty Calendar & Leading Individuals & Events \\
\hline 1736 & the 1st year of Qianlong & $\begin{array}{l}\text { Huang Tinggui } \\
\text { (Sichuan governor) }\end{array}$ & $\begin{array}{l}\text { Established four main ports and the } \\
\text { route of "Sichuan salt into Guizhou" }\end{array}$ \\
\hline 1743 & the 8th year of Qianlong & $\begin{array}{c}\text { Zhang Guangsi } \\
\text { (Guizhou governor-general) }\end{array}$ & The first river channel dredging \\
\hline 1877 & the 3rd year of Guangxu & $\begin{array}{c}\text { Ding Baozhen } \\
\text { (Sichuan governor-general) }\end{array}$ & $\begin{array}{l}\text { Reform of salt policy } \\
\text { The second river channel dredging }\end{array}$ \\
\hline 1941 & the 29th year of the Republic China & Nationalist Party's River committee & The third river channel dredging \\
\hline
\end{tabular}

* Compiled from gazetteers by the authors.

\subsubsection{Settlements along the Route}

To compare the differences in settlements before and after "Sichuan salt into Guizhou," the index of population and household changes was applied to determine the scale of development. All available historical demographic data on Chishui were collected and visualized. Furthermore, the findings from the literature provide cartographic evidence to represent the historical landscape of settlements.

"Sichuan salt into Guizhou" had a penetrating impact on the population of settlements along the Chishui River. According to the official statistics from the Chishui County gazetteer (1990), there were 5489 households in Chishui County in 1682, the 21st year of Kangxi. In the 41st year of Qianlong (1776), the number of households almost doubled, increasing to 9017 . Subsequently, the population tended to be stable in the Qing Dynasty, with 8999 households of 34,281 residents in 1820 and 8917 households of 35,064 residents in 1840 (see Figure 9a). In addition, Figure $9 \mathrm{~b}$ reveals that there was significant population growth after each regime changed. What can be clearly seen is the steady growth of the population since the 1980s, corresponding to the recent development of traditional settlements, such as Bing'an and Datong (see Figure 10).

- Population $\quad$ Households

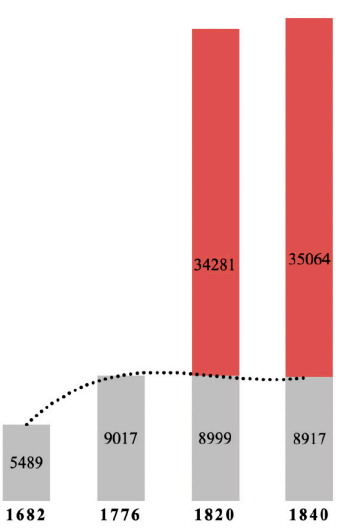

Time. Qing Dynasty

(a)

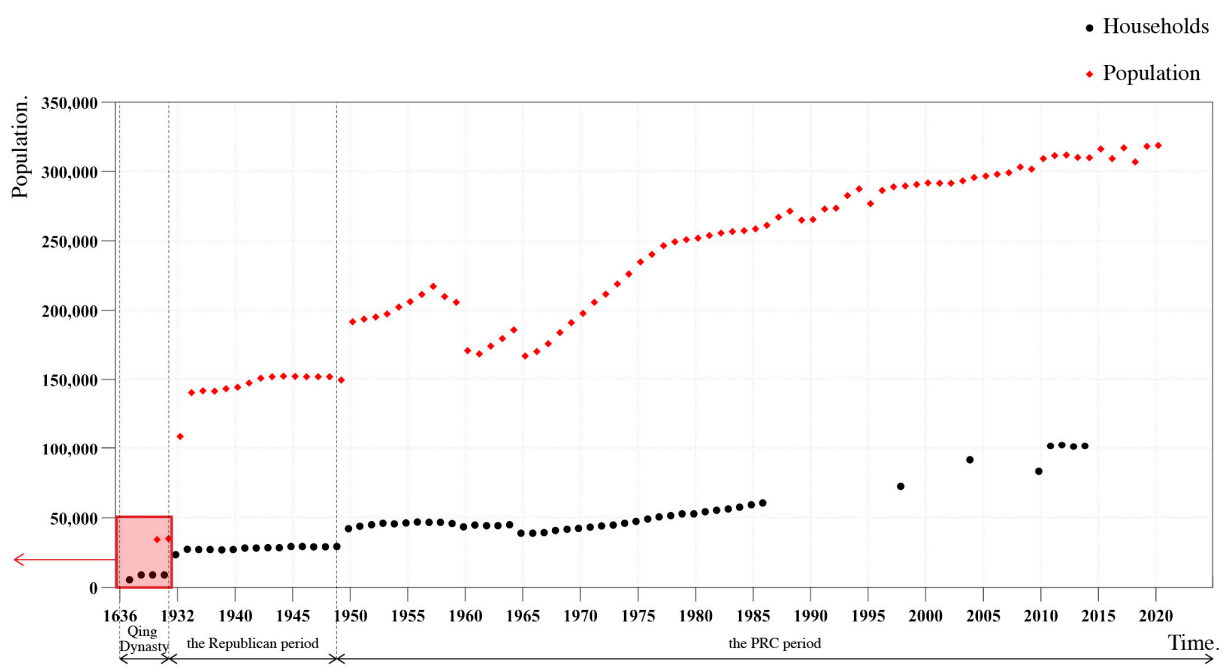

(b)

Figure 9. The population and households of the Chishui region since the Qing Dynasty. Source: Data from Chishui County gazetteer (1990), Chishui City gazetteer (1986-2006) and Yearbooks of Zunyi (1998-2020) (Zunyi Bureau of Statistics). Note: (a) The four years of statistical data available for the Qing Dynasty demonstrate that the population of Chishui significantly doubled between 1682 and 1776. (b) There was a distinct population growth after each regime changed. The population has grown steadily since the 1980s. The part of the time axis in the Qing Dynasty is compactly curtailed due to the limited data. 


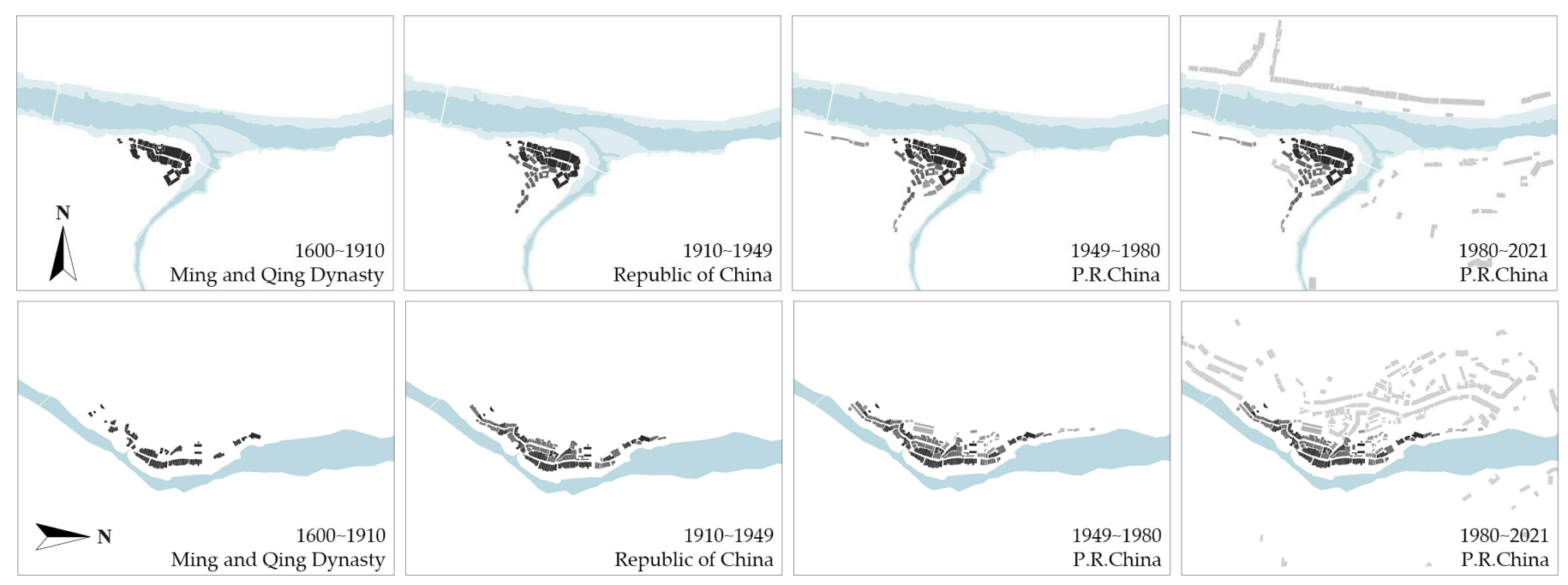

Figure 10. Diagram of the evolution of settlements. Up: Bing'an; Down: Datong. Source: authors' own work based on field survey. Note: The first to third sets of patterns are mostly traditional building types, while the light gray patterns in the fourth set represent modern building types.

To explain the phenomenon during "Sichuan salt into Guizhou", it is necessary to understand the most remarkable characteristic of rural society in traditional China, that is, the immobility of settlements. This enduring attachment to the soil demonstrates the relationship between people and space [45]. The population of human settlements is necessarily connected to arable land, which is sparsely distributed in mountains. Usually, the number of people in mountainous areas retain their rural stability unless natural disasters or human activities occur. Together, these results provide reasonable insight into the population explosion between 1682 and 1776, which reflects unusual external social changes, in accordance with the salt policies and correlated activities of "Sichuan salt into Guizhou" in the early Qianlong Period.

These political and economic activities opened up the Chishui port, attracting a large number of immigrants from Jiangxi, Jiangnan, and other central provinces. According to the Qing Dynasty open land policy, these people naturalized and became Guizhou people. They brought considerable wealth, as well as the culture and architectural technology of the Central Plain, to build commercial ports with streets and alleys similar to those in the Jiangnan area. They also built Jiangxi Hall, temples, and other foreign types of buildings. In the end, the foreign and the local and the new and the old integrated into a human landscape with a unique locality.

The most surprising aspect of the collected historical materials is in the visual landscape of these traditional villages. Considering that ancient Chinese cartography developed nearly a hundred years later than the West, it was not until the Kangxi era that a relatively scientific and accurate cartography appeared [46]. This ancient map is a special research resource depicting a landscape overlooking the Chishui River. From this, it is possible to clearly identify the rivers, road networks, mountain peaks, and five studied settlements (see Figure 11). The free sketch images illustrate the morphological characteristics of different settlements: (1) Datong is represented by a temple built on the mountain (corresponding to Guanyin Temple); (2) Fuxing is located in the almost plain terrain, forming a network of paths to parallel rivers; (3) the vernacular buildings in Bing' an were built on steep rocks, reflecting the characteristics of traditional wooden structure hanging houses; and (4) the other two, Hulu and Yuanhou, which are slightly farther away in the painting, showed public spaces in settlements.

In summary, the results of these historical analyses demonstrate that "Sichuan salt into Guizhou" was the essential dynamic force for the historical evolution of settlements in the Chishui Basin. This approach of referring to a large number of historical documents provides both literal and cartographic evidence, albeit sometimes indirectly. Furthermore, 
the process of spatial translation of historical maps has the potential to unveil some illuminating knowledge, which permits an immersive perception of the cultural landscape, social practices, and livelihoods of the rural world in the past. Despite the limited construction tools and technology, ancient craftsmen managed to create settlement landscapes with local characteristics in response to different topographical features. This information evokes reflection when we consider the empirical evidence of modern landscapes in rural areas.

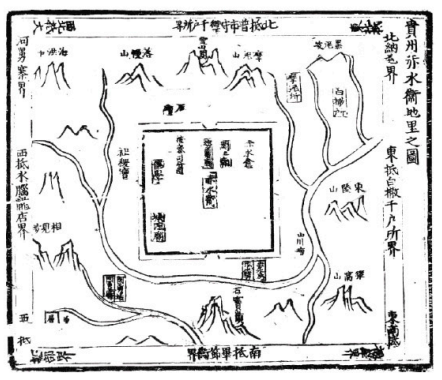

(a)
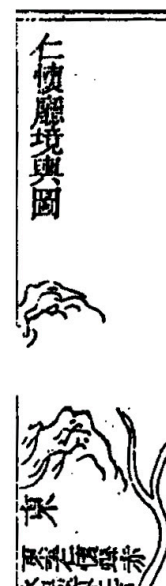
kt+4

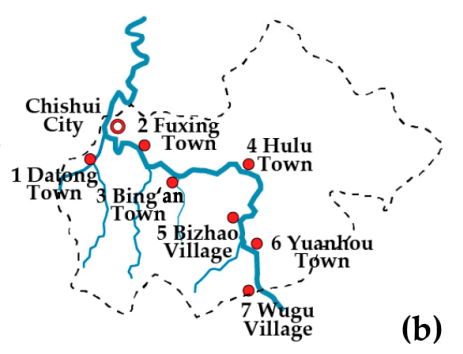

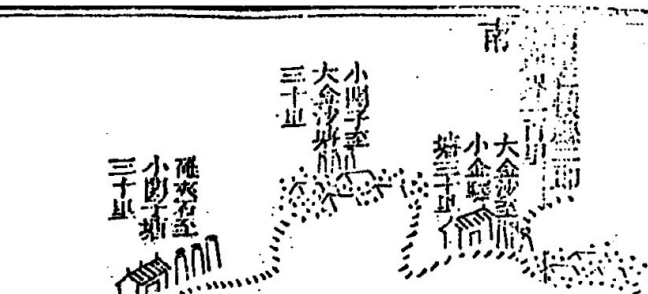
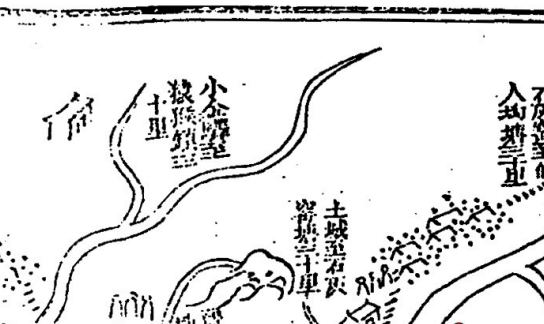

inin

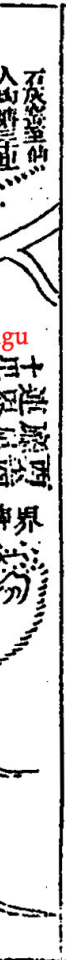

Figure 11. (a) Historical map of the Chishui Department, 1500. Source: Hongzhi Guizhou Tujingxinzhi 弘治贵州图经新志 (New Gazetteers of Guizhou in Hongzhi, Ming Dynasty). (b) Village landscape in Chishui County, 1841. Source: Adapted from Daoguang Renhuai Zhiliting Zhi 道光仁怀直隶厅志 (Gazetteers of Renhuai direct administration in Daoguang, Qing Dynasty).

\subsection{A Multi-Cultural Route in New Era}

\subsubsection{Route Shifting from Waterways to Highways}

With the process of modernization, the cultural route of salt transport has undergone substantial changes, reflected in the transition from waterways to highways. The first change was the terms of shipping on the Chishui River.

- Salt supply. After the founding of the People's Republic of China, the supply of salt in Guizhou was no longer a problem. In the past, however, salt transportation was so dangerous that crews and pickers had frequent accidents, which led to strikes and economic disputes. From 1950 onward, the government macroregulated and expanded the salt supply market to suppress the price of salt. The Chishui section of the Chishui-Tongzi highway (S301) was opened in 1959, which eased the demand for salt transportation on the Chishui River.

- Shipping modernization. In the late 1950s, several steamships were commissioned in the Chishui Basin, three of which were allocated from the central government. Infrastructure in the Chishui Basin was built sequentially, including hydroelectric power stations, bridges, and modern docks. The Chishui River has opened up routes for long-distance transportation in the middle and lower reaches of the Yangtze River and Chishui-Chongqing passenger transport. It was not until the dawn of the 21st century that shipping ceased and the ferry service to Chongqing stopped operating in 
2001. The following year, the Bing'an pedestrian bridge across the Chishui River was completed, and the Bing'an ferry was concurrently cancelled.

- Ecological restoration. For a long time, the biodiversity of the Chishui River basin continued to decline due to overfishing. The State Council approved the listing of the Chishui River in the "National Nature Reserve of Rare and Endemic fish in the upper reaches of the Yangtze River" in 2005. However, it failed to prevent the Guizhou section of the Chishui River from being severely polluted by 2012. China banned all fishing activities in the Chishui River basin from 2017 to 2026 to restore the ecological environment. The Decision on Strengthening the Joint Protection of the Chishui River basin entered into force in 2021 as a reliable guarantee of the rule of law. Yunnan, Guizhou and Sichuan provinces jointly established a 200 million RMB ecological compensation fund for the entire Chishui River Basin. Guizhou has revised the regulations accordingly, formulated and implemented reform programs such as the delineation of the ecological red line in the basin, and paid for the use of water resources, ecological compensation, third-party management of environmental pollution, and river chief systems to strengthen environmental supervision. Despite these recent findings regarding the declining role of river transport in the modern era, ecological restoration has arisen as the most critical issue for the Chishui River in recent decades. Nevertheless, the transportation function of waterways has been increasingly replaced by highways. The second change involved road construction.

- Highway construction. As mentioned above, road infrastructure has been carried out since 1959; however, it was not until forty years later that the last township road was completed in Chishui. At the end of 2013, the Renhuai-Chishui Expressway was opened to traffic, constituting a major part of the red tourism route as well as an economic trunk line. Since 2017, the construction of transportation infrastructure has been accelerated. As part of a full provincial transportation construction program, the Chishui River Valley Tourist Highway, which traces the historical salt waterway from Maotai to Chishui City, was officially completed in 2017. It consists of $160 \mathrm{~km}$ of mountain bike riding routes and $154 \mathrm{~km}$ of motorized routes, forming a slow-moving system to facilitate tourism alongside the river. The dramatic rise of road networks has created a new economic path for isolated towns in the southwestern region, bringing benefits to local residents and attracting tourists to boost the regional economy.

- Benefits and visions. Highway construction strengthens ethnic unity and progress, and further accelerates the development process in northern Guizhou by promoting local resource utilization, tourism development, and poverty alleviation. Initially, the government organized a series of historical conservation and rural planning projects on the basis of improved infrastructure. As a famous Chinese historical and cultural village and town, conservation plans were prepared for Bing'an (2012) and Datong (2019). Subsequently, development plans were organized and prepared for traditional town preservation, tourism, and poverty alleviation. Relying on the Chishui River Valley Highway, the Tourism Development Plan 2019-2030 is a medium- to long-term project aimed at enhancing the prosperity of the Basin Resort.

- Interference with settlements. Inevitably, however, highways bring some disadvantages to settlements. The new layouts are heavily dominated by road systems, reflecting the overwhelming priority of accessibility over topographic habitability in site selection, whereas traditional settlements follow the obverse logic. With respect to the environment, traditional habitats extend to the river by creeping along the mountainous alignment. As a result, new clusters were developed alongside the highway, disrupting the continuity of pedestrian systems and failing to create an orderly living space (see Figure 10). New clusters often lack a sense of spatial enclosure and disregard the scale of the streets and alleys. The terrible result that emerges in Bing'an is the tourist service buildings that lined the road and seriously obstructed the natural environment (see Figures 12 and 13). Although they are all predominantly linear, the 
old clusters have a certain thickness consisting of several rows of traditional long units (see Figure 14).

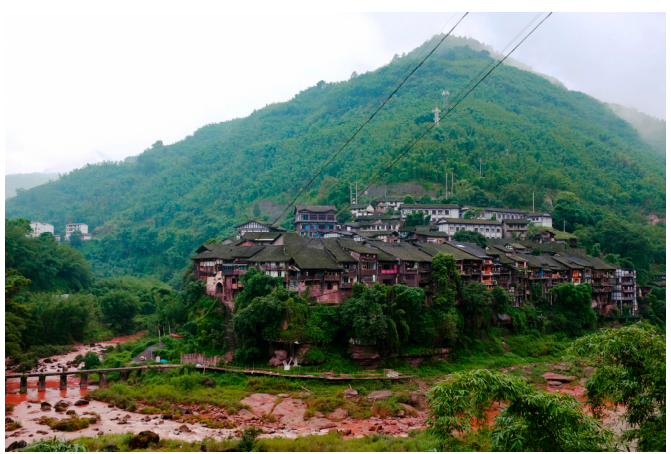

(a)

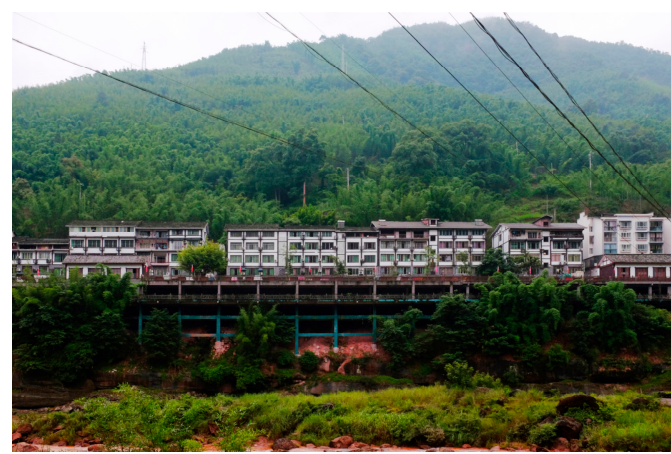

(b)

Figure 12. A comparison of the old and the new: Bing'an. (a) Traditional settlement; (b) The new settlements built along the highway. Photographs: by the authors.

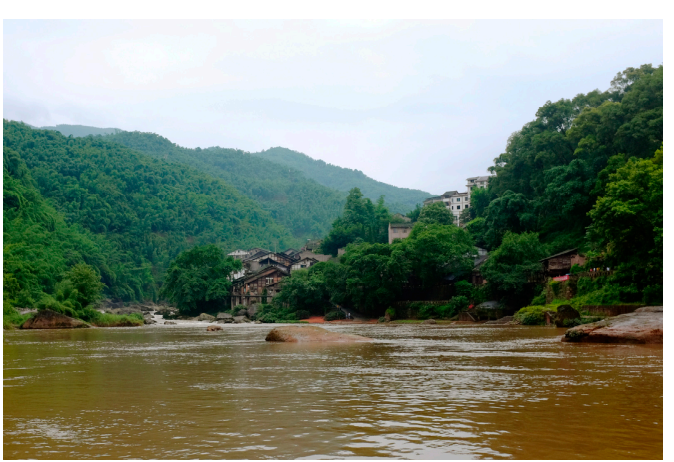

(a)

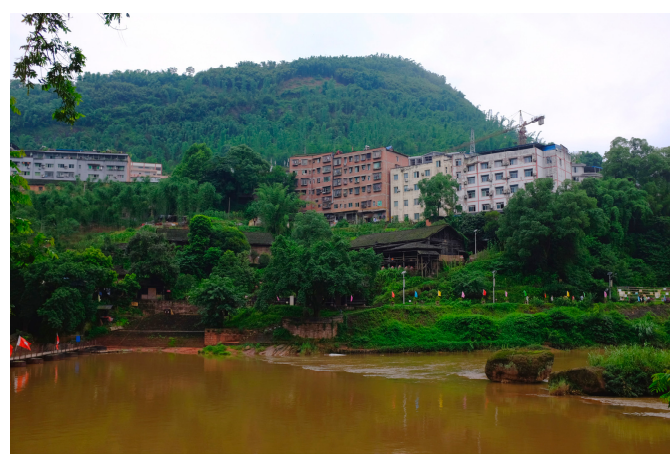

(b)

Figure 13. A comparison of the old and the new: Datong. (a) Traditional settlement; (b) New settlements incompatible with the natural environment. Photographs: by the authors.

\subsubsection{Cultural Heritage in Traditional Villages}

Notwithstanding the fact that the route has shifted and its original functions have been replaced, cultural heritage in both the route itself and adjacent settlements recorded the valuable elements of salt transportation culture through tangible and intangible resources (see Table 3). On the one hand, the salt transport culture participated in shaping the structure of towns, which is well preserved and serves as the context of cultural experience. The production and livelihood of the inhabitants were strongly influenced by "Sichuan salt into Guizhou". For instance, each major node of the salt route has a pair of docks that start and end at the main street, joining the waterway via a platform adjacent to the river (see Figure 14). Bing'an has a series of route heritage sites, such as the 1.7-m-wide Double Dragon Bridge, the 63-m-long stone staircase, and the 500-m-long ancient salt road at the water's edge.

The street system forms part of the settlements and the cultural route through the route itself. The main commercial streets, the 2-to 5-m-wide stone streets, are enclosed by long unit buildings with a slope or steps along the terrain leading to higher ground. The common long units have the typical patterns of stores in front and bedrooms in back. As far as public spaces in the valley villages are concerned, the joint plaza at the docks and town gates is the most collective space, and there is little large-scale outdoor space in the compact streets. The 500-year-old lower dock of Datong, $33 \mathrm{~m}$ long and $4.5 \mathrm{~m}$ wide, played an important role in history. 


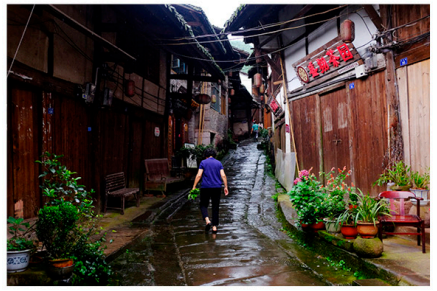

Traditional Salt Path

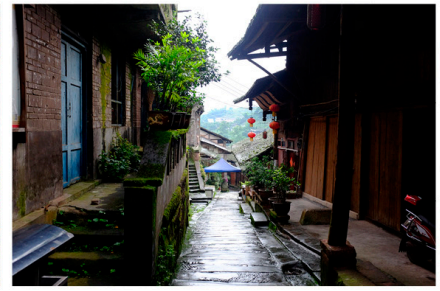

Traditional Salt Path

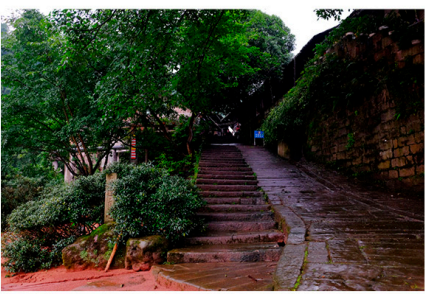

Lower Dock

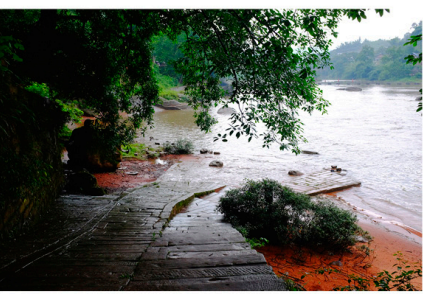

Lower Dock

(a)

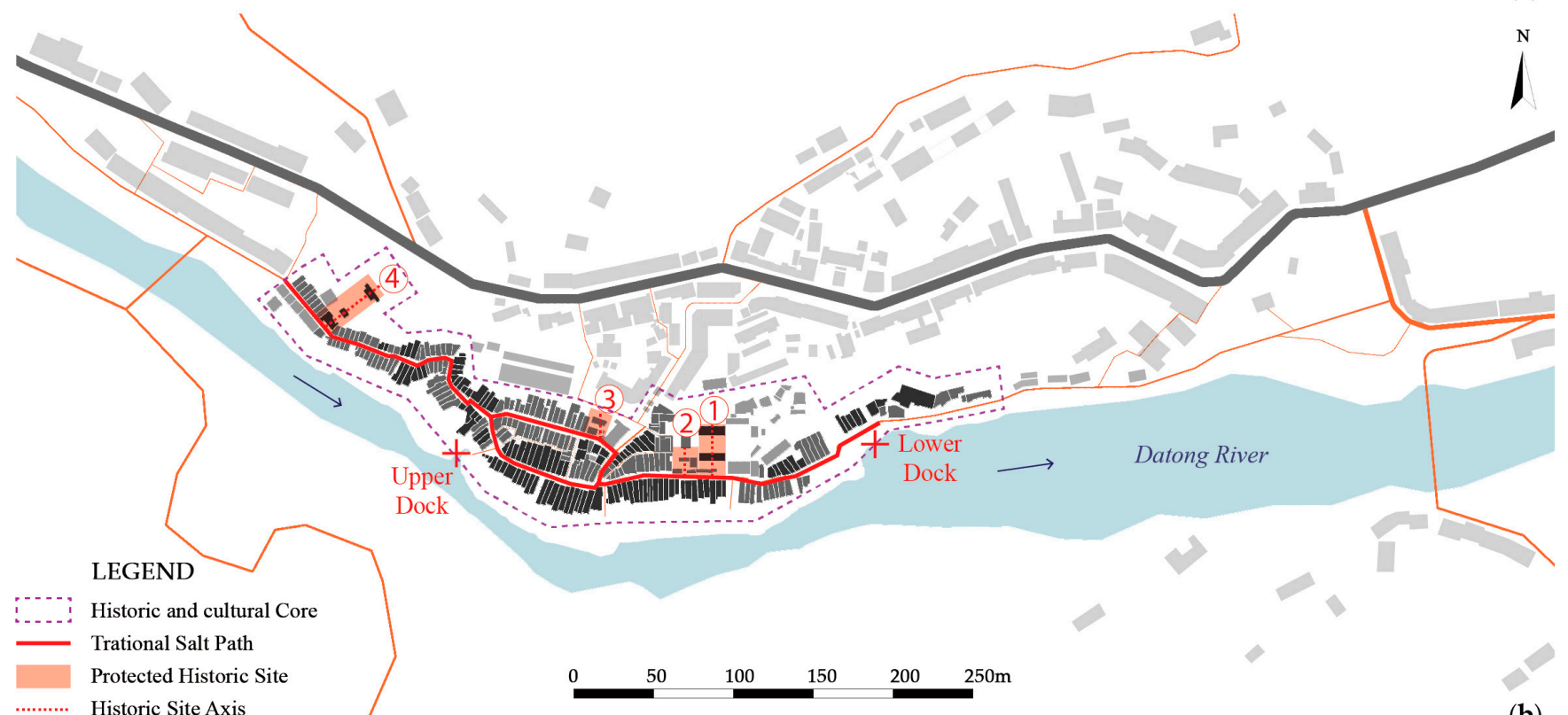

$\mathrm{N}$

(b)

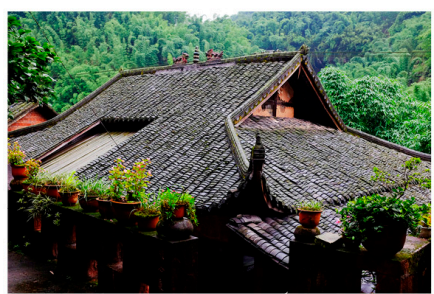

(3)

4 Guanyin Temple

(4)

$\checkmark$ King Yu's Palace
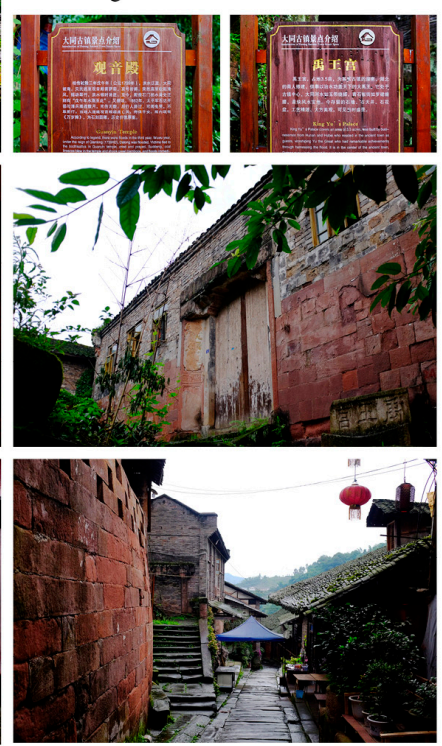
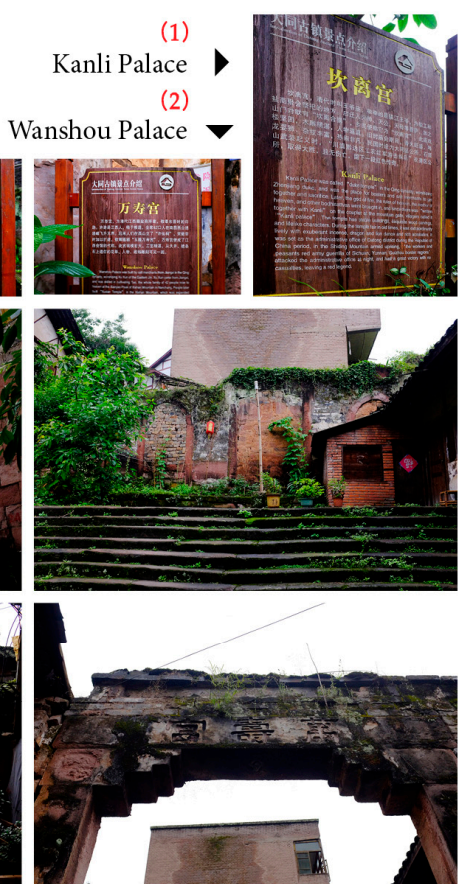
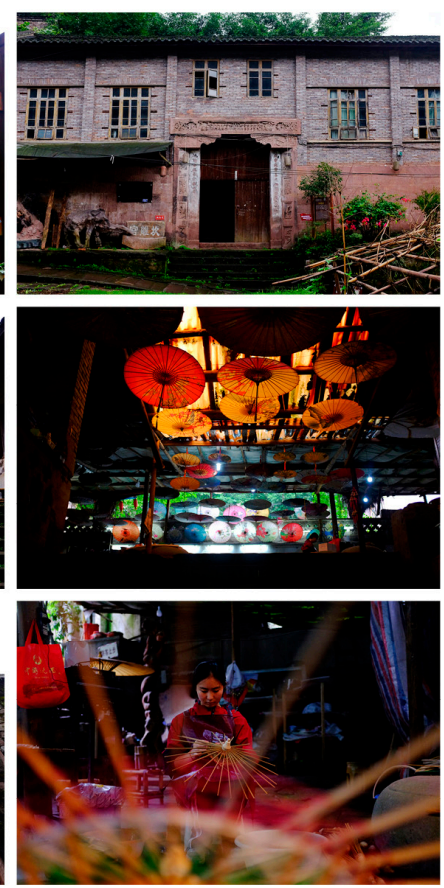

(c)

Figure 14. Cultural Heritage in Datong. (a) Identifying the salt route through construction elements; (b) Morphological structural analysis of the historic core; (c) Protection of historic sites involved with the salt transportation culture have been conserved and exhibited at different levels. Source: authors' own work. Photography: the authors. 
Table 3. Tangible Cultural Elements in Datong.

\begin{tabular}{|c|c|c|c|c|c|c|}
\hline $\begin{array}{l}\text { Element } \\
\text { Type }\end{array}$ & Time & Site & Function & Patron & Worship God & Events \\
\hline Construction & $\begin{array}{c}\text { Ming } \\
\text { Dynasty }\end{array}$ & $\begin{array}{l}\text { Lower Dock } \\
\text { Upper Dock }\end{array}$ & Salt port & $\begin{array}{l}\text { Government and } \\
\text { indigenous people }\end{array}$ & & $\begin{array}{l}\text { "Sichuan salt } \\
\text { into Guizhou" }\end{array}$ \\
\hline \multirow{4}{*}{ Architecture } & \multirow{4}{*}{$\begin{array}{l}\text { Qing } \\
\text { Dynasty }\end{array}$} & $\begin{array}{l}\text { (1) Kanli } \\
\text { Palace }\end{array}$ & $\begin{array}{l}\text { Meeting, Worship, } \\
\text { Temple fair }\end{array}$ & Salt merchants & $\begin{array}{c}\text { River God: } \\
\text { Zhenjiang Duke }\end{array}$ & $\begin{array}{c}\text { an armed } \\
\text { uprising in } 1935\end{array}$ \\
\hline & & $\begin{array}{l}\text { (2) Wanshou } \\
\text { Palace }\end{array}$ & $\begin{array}{c}\text { Jiangxi Guild Hall, } \\
\text { Worship }\end{array}$ & $\begin{array}{l}\text { Jiangxi Salt } \\
\text { merchants }\end{array}$ & Tao: Xu Xun & \\
\hline & & $\begin{array}{l}\text { (3) King Yu's } \\
\text { Palace }\end{array}$ & Worship & $\begin{array}{l}\text { Hunan/Hubei } \\
\text { merchants }\end{array}$ & $\begin{array}{l}\text { King Yu who } \\
\text { tamed the flood }\end{array}$ & \\
\hline & & $\begin{array}{l}\text { (4) Guanyin } \\
\text { Temple }\end{array}$ & Worship, Salvation & Indigenous people & $\begin{array}{l}\text { Buddha: } \\
\text { Guanyin }\end{array}$ & $\begin{array}{l}1739 \text { floods } \\
1862 \text { war }\end{array}$ \\
\hline
\end{tabular}

* Authors' own elaboration.

Architecture is the physical container of the salt transport culture while reflecting its symbolic sense. Taking Datong as an example, four monuments built during the Qing Dynasty were preserved; all were related to river culture, reflecting an interesting cultural phenomenon of water fear, water management, and water use in ancient times (see Figure 14). Among them, Guanyin Temple and Kanli Palace are well preserved and available for daily use. Guanyin Temple maintains its original functions of worship and salvation with an endless stream of pilgrims. In contrast, Kanli Palace has been endowed with different cultural contents at different times, once serving as a collective place for crew unions, Red Army garrisons, and a meeting house. Currently, it acts as a production and exhibition hall for the intangible cultural heritage of oil paper umbrellas. The site of Wanshou Palace is in ruins, with part of the enclosure structure still remaining. The walls of King Yu's palace are overlapped by stones and bricks from various eras, recalling Victor Hugo's belief that the history of architecture is the history of writing.

In short, the abundant cultural heritage of salt transport that persists in traditional villages perpetuates the value of cultural routes in contemporary times. By assigning new dimensional functions, the established conservation has the potential to develop further as a living culture.

\subsubsection{Multi-Cultural Route for Rural Revitalization}

Prior studies that have examined cultural continuity rely on historical literature, maps, tangible heritage, and their modern transformation, which may support the hypothesis of an integration model. Cultural routes are currently subject to multiple and often overlapping elements of both cultural and natural heritage [47]. Well-preserved cultural heritage in traditional villages has the potential to reveal itself in landscape corridors, further representing the entire cultural route. The following is a multi-level exploration of the paths by which the concept of cultural routes can be applied to connect linear cultural heritage sites and revitalize villages along the route (see Figure 15).

1. From a topographical perspective, landforms are the basis of human activities, while the river serves as the route's ontology [48]. Ecological restoration programs are expected to recall the historical salt transport route through experiential programs in the future. Alsophila vegetation cover has been protected as a national nature reserve. According to the local conditions, the implementation of returning fallow to bamboo forest makes bamboo a powerful tool to combat poverty and promote rural revitalization. This concept as well as biodiversity conservation and recreation are the most frequent scope of landscape corridors [49], and they share some of the same values as cultural routes. Cultural heritage is mainly present in traditional settlements, including the route ontology and other substantial elements.

2. From a plural time perspective, Braudel identified three dimensions of history and social time that have cultural potential [50]. First, the environmental effects of the longue durée have framed the geographical ground of the human route. Second, cycli- 
cal human activities involving socio-economic and cultural attributes have formed historical transportation routes that have lasted for hundreds of years. In parallel to transporting goods, the route also transported migrants and disseminated culture, which created a unique cultural landscape in the basin. These influences eventually manifested in the patterns and townscapes of traditional settlements. Finally, the events of the "four crossings of the Chishui River" are concentrated in recent history and overlaid on cultural routes to render the Red Culture alive.

3. From a rural governance perspective, three main forces affect the tourism development of cultural routes. The government establishes regulations and leads rural construction from top to bottom, while the marketplace serves as the implementation platform for the conversion of capital to the countryside into rural operations [51]. However, the bottom-up approach, through the everyday life of the inhabitants, has undeniable weight for the preservation and sustained adoption of cultural routes. Furthermore, the connected nature of cultural routes requires cooperation in governance and management at the village-to-village, settlement, and regional levels.

4. From a tourism perspective, a multi-cultural route may proceed from three symbolic paths: a waterway in blue, a landscape corridor in green, and a cultural route in red. The multi-cultural route has remarkably expanded its scope and purposes within the above paths. The appeal of a single element is limited, while a multi-cultural framework integrates landscape corridors and cultural routes as a whole with far more significant attractions, similar to how ancient routes have performed in the past. Market-oriented tourism can implement cultural routes while bringing about the flow and intermingling of people, capital, and culture, which ultimately contributes to the upgrading of infrastructure and the improvement of the living standards of its inhabitants.

A Multi-cultural Route Model

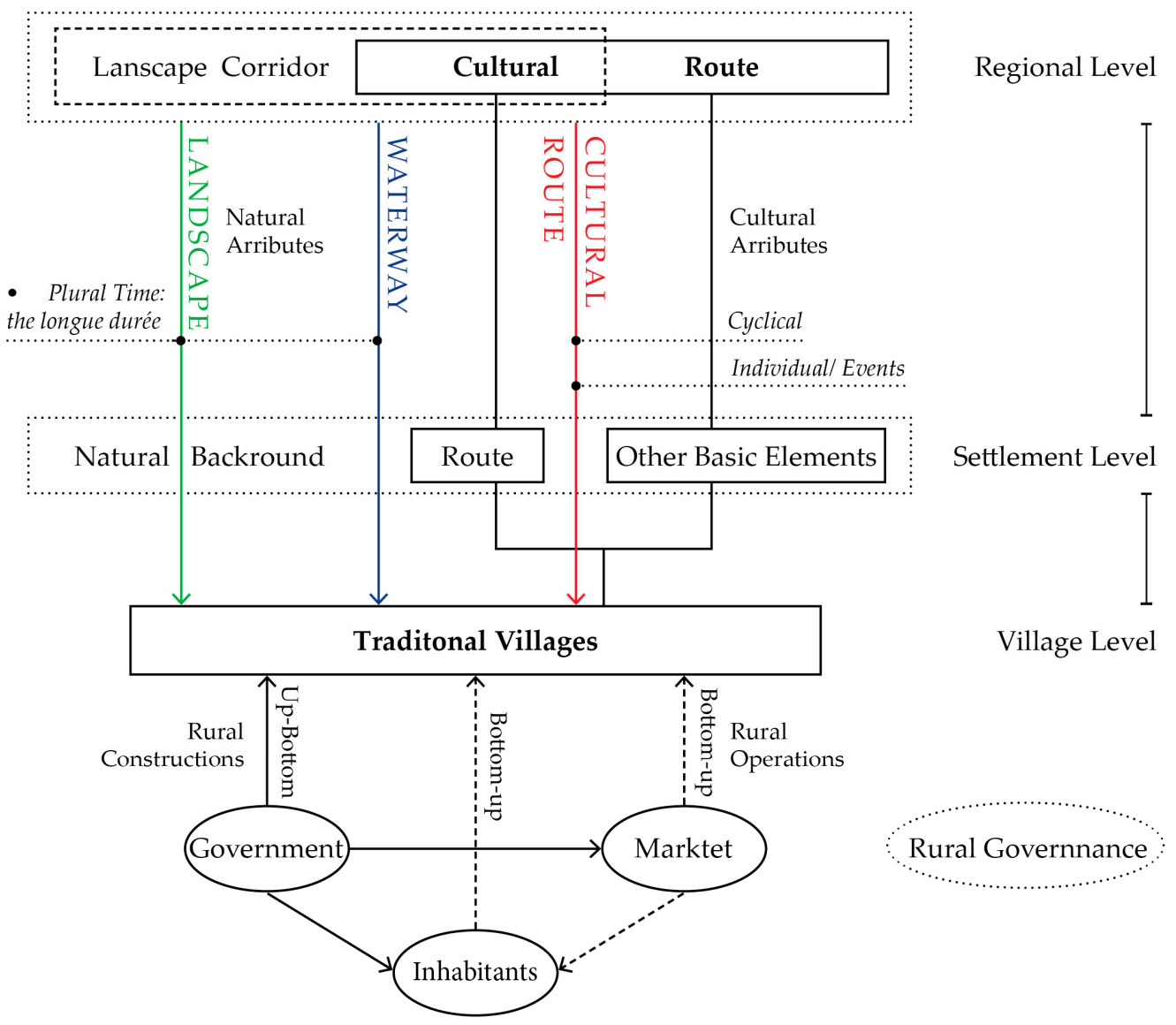

Figure 15. A Conceptual Model of a Multi-cultural Route. 
This section examines the route shift in contemporary times, cultural heritage in traditional villages and feasible revitalization paths that depend on cultural routes. First, the routes turned from waterways to highways, with ecological restoration of the original route. The highway construction brought obvious economic and development benefits to settlements, but it also involved some contradictions between the old and the new. Second, the current situation of cultural heritage is examined to seek the potential of cultural routes, with Datong as an example. Finally, a conceptual model of a multi-cultural route is proposed to envision the modern utilization of cultural routes. Sustainable development requires ongoing attention to ecological governance, reaffirmation of the historical value of routes, market-oriented tourism industry, and local practices.

\section{Conclusions and Discussion}

As a mirror of traditional Chinese society, the spatial evolution of traditional villages reflects the unconventional nature of rural China, which hinders a full understanding through the universal values and methods of modernism. In anthropology and sociology, this sense of local cultural crisis in regionalism emerged much earlier. Fei Xiaotong attempted to construct a non-Western theoretical foundation for the sociology of Chinese society in the 1950s [45]. Through field investigation in Guizhou and other southwest regions, he proposed the concept of an ethnic corridor, although this work has not received the attention and continuity it deserves. Family culture in rural China was another sociological exploration of modernization raised in the 1990s [52]. Scientific discussions on urban-rural duality have attempted to bridge the gap institutionally and socio-economically [53]. Wen Chunlai made a dynamic historical construction of northwestern Guizhou, demonstrating that regional organization and the national system and the local and national identity are intertwined as one body with two sides [54,55]. As a result of the "spatial turn" in human sciences [56,57], these studies have laid the theoretical foundation to study the formal evolution of contemporary villages. This paper extends this interest from a dynamic spatial perspective in hopes of complementing anthropologic and spatial solicitude for rural issues.

Based on the initial twin foci of conservation and construction [58], this paper seeks to address the cultural sustainability issues in rural areas by tracing the cultural route and its associated settlements, both historical and contemporary. The traditional villages on the lower reaches of the Chishui River, together with the waterway, formed the cultural route of "Sichuan salt into Guizhou" since the Qing Dynasty. From point to line, it constituted a dynamic system that influenced the spatial development of the region. In the past half century, this waterway has gradually been replaced by highway construction and it has lost its previous functions. However, these traditional villages still sustain the spatial order of the cultural route and conserve the historic sites, which are a good foundation for rural revitalization. Cultural routes are considered in a broader dimension of history and social time. Combined with the landscape corridor of geographical time and the Red cultural events time, a multi-cultural route model is proposed to promote the comprehensive revitalization for the feature conservation type. The resulting model offers a line-to-region reference for design work on the revitalization modes and tourism strategies of traditional villages. This empirical project has been demonstrated to be valid in itself; however, at a larger practical level, a predicament remains between development and preservation in rural China $[59,60]$.

In the course of the argument, we have referred to a wide range of historical documents that provide evidence, albeit sometimes indirect, that serves both to reinforce and to replenish the chains of inference that constitute the main thread. This study enriches existing knowledge of cultural routes by interpreting their initial spatial development and recent transformation, that is, traditional versus modern. This pair of eternal opposites is not necessarily a contradiction. They can be integrated in the same process through a multicultural route that proposes a historico-geographical framework toward modernization through a proper extension of traditional culture and natural attributes. This framework is 
also firmly rooted in the wider realm of social and economic processes [61] concerning the imperceptible effect of the environment $[39,62]$, which provides a methodological reference for other rural settlements facing a similar dilemma.

The scope of this study was limited in terms of the inheritance and innovation of traditional livelihood models, policy mechanisms, and the preservation of ecological heritage. The study was conducted in the context of traditional villages. For rural areas that do not have an uninterrupted traditional cultural base, the model of cultural routes may not be applied directly. By 2019, five batches of catalogs of national traditional villages were published containing 6809 villages, of which Guizhou had 724 and ranked first in the country [63]. Future research can be conducted in other types of traditional villages in a mountainous-basin environment where ethnic culture and family culture may give rise to new models of rural revitalization.

Author Contributions: Conceptualization, Z.Z. and X.Z.; methodology, Z.Z.; investigation, Z.Z.; writing-original draft preparation, Z.Z.; writing—review and editing, Z.Z.; visualization, Z.Z.; supervision, X.Z. All authors have read and agreed to the published version of the manuscript.

Funding: This research received no external funding.

Institutional Review Board Statement: Not applicable.

Informed Consent Statement: Not applicable.

Data Availability Statement: Not applicable.

Acknowledgments: Z.Z. thanks Jie P. Li for commenting on the draft manuscript. The authors thank the anonymous reviewers for their constructive comments on improving this research.

Conflicts of Interest: The authors declare no conflict of interest.

\section{References}

1. Bochkov, D. Multiple nature-cultures, diverse anthropologies. Soc. Anthropol. 2020, 28, 538-539. [CrossRef]

2. Cloke, P. Country backwater to virtual village? Rural studies and 'the cultural turn'. J. Rural Stud. 1997, 13, 367-375. [CrossRef]

3. Jokinen, A. Free-time habitation and layers of ecological history at a southern Finnish lake. Landsc. Urban Plan. 2002, 61, 99-112. [CrossRef]

4. Duan, J.; Shao, R.; Lan, W.; Liu, J.; Jiang, Y. Space Gene. City Plan. Rev. 2019, 43, 14-21.

5. Peng, Y. Landscape Analysis of Traditional Villages; China Architecture \& Building Press: Beijing, China, 1994.

6. Chen, Z. Traditional Villages in the Middle Reaches of Nanxi River; SDX Joint Publishing Company: Beijing, China, 1999.

7. Duan, J. Analysis of Town Space: Spatial Structure and Morphology of Ancient Towns in Taihu River Basin; China Architecture \& Building Press: Beijing, China, 2002.

8. Qin, X.F.; Li, Y.R.; Lu, Z.; Pan, W. What makes better village economic development in traditional agricultural areas of China? Evidence from 338 villages. Habitat Int. 2020, 106, 102286. [CrossRef]

9. Katapidi, I. Heritage policy meets community praxis: Widening conservation approaches in the traditional villages of central Greece. J. Rural Stud. 2021, 81, 47-58. [CrossRef]

10. Kai, G.U. Urban morphology: An introduction and evaluation of the theories and the methods. City Plan. Rev. 2001, 25, 36-42. [CrossRef]

11. Chen, J.; Yao, S.; Tian, Y. The Theory and Localization About Typo-morphological Approach. Urban Plan. Int. 2017, 32, 57-64. [CrossRef]

12. Whitehand, J.W.; Gu, K.; Whitehand, S.M.; Zhang, J. Urban morphology and conservation in China. Cities 2011, 28, 171-185. [CrossRef]

13. Li, X. From the City to the Construction: A New Dimension in the Architecture of the City. World Archit. 2021, 10, 17-22. [CrossRef]

14. Guo, P.; Ding, W. A Study on a Collective Architectural Type and the Morphology of a Villagey: A Case Study of Shangzhuang Village in Yangcheng, Shanxi Province. Archit. J. 2017, 05, 80-86. [CrossRef]

15. Guo, P.; Ding, W. Towards a Synthetic Typology: The Comparision between the Third Typology and Typomorphology. Architect 2017, 01, 36-44.

16. Yamu, C.; van Nes, A.; Garau, C. Bill Hillier's Legacy: Space Syntax-A Synopsis of Basic Concepts, Measures, and Empirical Application. Sustainability 2021, 13, 3394. [CrossRef]

17. Yin, L.; Wang, T.; Adeyeye, K. A Comparative Study of Urban Spatial Characteristics of the Capitals of Tang and Song Dynasties Based on Space Syntax. Urban Sci. 2021, 5, 34. [CrossRef]

18. Nash, C. Genealogical identities. Environ. Plan. D Soc. Space 2002, 20, 27-52. [CrossRef] 
19. Wang, J.Y. Cultural Route as a Type of World Heritage:An Interpretation to the ICOMOS Charter on Cultural Routes. Urban Plan. Forum 2009, 04, 86-92.

20. Cambridge University Press. ICOMOS Charter on Cultural Routes: Prepared by the International Scientific Committee on Cultural Routes (CIIC) of ICOMOS. In Proceedings of the 16th General Assembly of ICOMOS, Québec, QC, Canada, 4 October 2008. [CrossRef]

21. Liu, S.; Li, Q.H.; Gan, F.; Zhang, P.; Lankton, J.W. Silk Road glass in Xinjiang, China: Chemical compositional analysis and interpretation using a high-resolution portable XRF spectrometer. J. Archaeol. Sci. 2012, 39, 2128-2142. [CrossRef]

22. Severo, M. European Cultural Routes: Building a Multi-Actor Approach. Mus. Int. 2017, 69, 136-145. [CrossRef]

23. Grabow, S. The Santiago de Compostela Pilgrim Routes: The Development of European Cultural Heritage Policy and Practice from a Critical Perspective. Eur. J. Archaeol. 2010, 13, 89-116. [CrossRef]

24. Snowball, J.D.; Courtney, S. Cultural heritage routes in South Africa: Effective tools for heritage conservation and local economic development? Dev. S. Afr. 2010, 27, 563-576. [CrossRef]

25. Terzić, A.; Bjeljac, Ž.; Jovičić, A.; Pejnišević, I. Cultural Route and Ecomuseum Concepts as a Synergy of Nature, Heritage and Community Oriented Sustainable Development Ecomuseum "Ibar Valley" in Serbia. Eur. J. Sustain. Dev. 2014, 3, 1-16. [CrossRef]

26. Hackenberg, R.A. Closing the Gap Between Anthropology and Public Policy: The Route Through Cultural Heritage Development. Hum Organ. 2002, 61, 288-298. [CrossRef]

27. Bai-hao, L.; Jianhua, Z.; Li, H.; Jian, G. One cultural route span the millenary: Chinese Tea Road. In Proceedings of the Monuments and Sites in Their Setting-Conserving Cultural Heritage in Changing Townscapes and Landscapes, Xi'an China, 17-21 October 2005.

28. Oikonomopoulou, E.; Delegou, E.T.; Sayas, J.; Moropoulou, A. An innovative approach to the protection of cultural heritage: The case of cultural routes in Chios Island, Greece. J. Archaeol. Sci. Rep. 2016, 14, 742-757. [CrossRef]

29. Pei, H. "Sell Salt from Sichuan to Guizhou" and the Social Interaction along Chishui River Valley. J. Sichuan Univ. Sci. Eng. Soc. Sci. Ed. 2012, 27, 14-19.

30. Luo, J.; Wei, D. Study on the route of Sichuan salt from Ren'an River into Guizhou and its role. J. Anhui Agric. Sci. 2012, 40, 3006-3008. [CrossRef]

31. $\mathrm{Wu}, \mathrm{X}$; Lou, $\mathrm{Q}$. Research on the conservation of linear cultural heritage in southwest China: The example of the route of Sichuan salt into Qian. Guizhou Soc. Sci. 2017, 329, 44-48. [CrossRef]

32. Song, N.; Jin, Q. On the Influence of the Course for Salt Transportation from Sichuan to Guizhou upon the Economy in Chishui district. J. Zunyi Norm. Coll. 2016, 18, 27-29. [CrossRef]

33. Zhou, Z.; Cheng, S. A Study on the Morphology and Survival Rationality of Ethnic Buyi Settlements in Baishui Valley, Guizhou Province. Archit. J. 2018, 3, 101-106. [CrossRef]

34. Zhou, Z.; Jia, Z.; Wang, N.; Fang, M. Sustainable Mountain Village Construction Adapted to Livelihood, Topography, and Hydrology: A Case of Dong Villages in Southeast Guizhou, China. Sustainability 2018, 10, 4619. [CrossRef]

35. Liu, J.; Li, D. Research of Multiple Time-space Cultural Superimposition in Siduchishui Area. Urban Dev. Stud. 2014, 21, 114-119.

36. Tuan, Y.F. Topophilia: A Study of Environmental Perceptions, Attitudes, and Values; Columbia University Press: New York, NY, USA, 1990; pp. 59-74.

37. Tuan, Y.F. Space and Place: The Perspective of Experience. University of Minnesota Press: Minneapolis, MN, USA, 1977; pp. 101-117.

38. Blanco, A.; de Bustamante, I.; Pascual-Aguilar, J.A. Using old cartography for the inventory of a forgotten heritage: The hydraulic heritage of the Community of Madrid. Sci. Total Environ. 2019, 665, 314-328. [CrossRef] [PubMed]

39. Whitehand, J.W.R. Basis for an Historical Geographical Theory of Urban Form. Trans. Inst. Br. Geogr. 1977, 2, 400-416. [CrossRef]

40. Whitehand, J.W.R. Green space in urban morphology: A historico-geographical approach. Urban Morphol. 2019, $23,5-17$.

41. Ruiz, R.; Rodriguez, J.; Coronado, J.M. Modern roads as UNESCO World Heritage sites: Framework and proposals. Int. J. Herit. Stud. 2017, 23, 362-374. [CrossRef]

42. Luo, Y.; Qi, L. Construction and practice of a conservation plan implementation evaluation system for historic villages. J. Asian Archit. Build. Eng. 2019, 18, 351-361. [CrossRef]

43. Dretske, F.I. Laws of Nature. Philos. Sci. 1977, 44, 248-268. [CrossRef]

44. Torbert, P.M. The Ch'ing Imperial Household Department: A Study of Its Organization and Principal Functions, 1662-1796; Council on East Asian Studies, Harvard University: Cambridge, MA, USA, 1977.

45. Fei, X. From the Soil, the Foundations of Chinese Society: A Translation of Fei Xiaotong's Xiangtu Zhongguo, with an Introduction and Epilogue; University of California Press: Berkeley, CA, USA, 1992.

46. Conzen, M.P.; Gu, K.; Whitehand, J.W.R. Comparing Traditional Urban Form in China and Europe: A Fringe-belt Approach. Urban Geogr. 2012, 33, 22-45. [CrossRef]

47. Liu, Y.; Li, F.; Li, X. The Path and Strategy of the Revival of Old City in the View of Cultural Routes-Taking Lingchuan County of Shanxi Province as an Example. Chin. Landsc. Archit. 2021, 37, 71-76. [CrossRef]

48. Zakariya, K.; Ibrahim, P.H.; Wahab, N.A.A. Conceptual Framework of Rural Landscape Character Assessment to Guide Tourism Development in Rural Areas. J. Constr. Dev. Ctries. 2019, 24, 85-99. [CrossRef]

49. Xu, H.Y.; Plieninger, T.; Primdahl, J. A Systematic Comparison of Cultural and Ecological Landscape Corridors in Europe. Land 2019, 8, 41. [CrossRef] 
50. Braudel, F. History and the Social Sciences: The Longue durée. In On History, 2nd ed.; University of Chicago Press: Chicago, IL, USA, 1982; pp. 25-54.

51. Aigwi, I.E.; Filippova, O.; Ingham, J.; Phipps, R. From drag to brag: The role of government grants in enhancing built heritage protection efforts in New Zealand's provincial regions. J. Rural Stud. 2021, 87, 45-57. [CrossRef]

52. Wang, H. Contemporary Chinese Village Family Culture: An Exploration of the Modernization of Chinese Society; Shanghai Renmin Chubanshe: Shanghai, China, 1991.

53. Li, Y. The Reform of the Rural-Urban Dualism. J. Peking Univ. Philos. Soc. Sci. 2008, 45, 5-11.

54. Wen, C. Zhenggang LIU, “Floating East and Marching West: A Comparison between Taiwan and Sichuan about Fujianese and Cantonese Immigrants in the Qing Period". J. Hist. Anthropol. 2006, 4, 186-190.

55. Wen, C. Ethnic Distinctions and Ethnic Transformation. J. Hist. Anthropol. 2004, 2, 33-49.

56. Stanek, L. Architecture as Space, Again? Notes on the Spatial Turn. Le J. Speciale'Z 2012, 4, 48-53.

57. Munn, N.D. The Cultural Anthropology of Time: A Critical Essay. Annu. Rev. Anthropol. 1992, 21, 93-123. [CrossRef]

58. Song, X.; Cheong, K.C.; Wang, Q.Y.; Li, Y.R. Developmental Sustainability through Heritage Preservation: Two Chinese Case Studies. Sustainability 2020, 12, 3705. [CrossRef]

59. Zhang, D.S.; Gao, W.; Lv, Y.Q. The Triple Logic and Choice Strategy of Rural Revitalization in the 70 Years since the Founding of the People's Republic of China, Based on the Perspective of Historical Evolution. Agriculture 2020, 10, 125. [CrossRef]

60. Zhou, Y.J.; Shen, Y.; Yang, X.X.; Wang, Z.F.; Xu, L.Y. Where to Revitalize, and How? A Rural Typology Zoning for China. Land 2021, 10, 1336. [CrossRef]

61. Rausch, A. Cultural Commodities in Japanese Rural Revitalization: Tsugaru Nuri Lacquerware and Tsugaru Shamisen; Brill: Leiden, The Netherlands, 2010; pp. 33-62.

62. Shen, J.; Chou, R.J. Cultural Landscape Development Integrated with Rural Revitalization: A Case Study of Songkou Ancient Town. Land 2021, 10, 406. [CrossRef]

63. Wu, C.; Chen, M.M.; Zhou, L.; Liang, X.J.; Wang, W. Identifying the Spatiotemporal Patterns of Traditional Villages in China: A Multiscale Perspective. Land 2020, 9, 449. [CrossRef] 